\title{
Hedge Funds as Investors of Last Resort?
}

\author{
David J. Brophy \\ University of Michigan \\ Paige P. Ouimet \\ University of Michigan
}

\section{Clemens Sialm}

University of Texas at Austin and NBER

\begin{abstract}
Hedge funds have become important investors in public companies raising equity privately. Hedge funds tend to finance companies that have poor fundamentals and pronounced information asymmetries. To compensate for these shortcomings, hedge funds protect themselves by requiring substantial discounts, negotiating repricing rights, and entering into short positions of the underlying stocks. We find that companies that obtain financing from hedge funds significantly underperform companies that obtain financing from other investors during the following two years. We argue that hedge funds are investors of last resort and provide funding for companies that are otherwise constrained from raising equity capital. (JEL G14, G23, G32)
\end{abstract}

Hedge funds have recently become an important source of funding for public companies raising equity privately. Financing young companies with severe information asymmetries is an important investment strategy for some hedge funds. Since 1995, hedge funds have participated in more than $50 \%$ of the private placements of equity securities and have contributed about one-quarter of the capital raised in such equity issuances, a total investment that has exceeded the contributions of other investor classes. This paper sheds light on the role of hedge funds in such private placements.

In perfect financial markets it should be irrelevant whether a firm obtains funding from hedge funds or from other investors. To investigate whether the identity of the investors matters, we use a unique dataset that

We thank Sugato Bhattacharyya, Serdar Dinc, Amy Edwards, Ken French, Radha Gopalan, Michael Hertzel, David Hsieh, Marcin Kacperczyk, Arif Khurshed, Han Kim, Alok Kumar, Bob Kyle, Augustin Landier, Tom Nohel, Richard Priestley, Uday Rajan, Amit Seru, Sophie Shive, Tyler Shumway, Vijay Singal, Matt Spiegel (the editor), Jeremy Stein, Joe Warburton, Xueping Wu, Lu Zheng, an anonymous referee, and seminar participants at the 2004 European Financial Management Association, the 2005 European Finance Association, the 2006 Financial Intermediation Research Conference, the Board of Governors of the Federal Reserve System, the U.S. Securities and Exchange Commission, and the University of Michigan for helpful comments and discussions. We are very grateful to Sagient Research for providing us with the PIPEs data. A previous version of this paper was circulated as "PIPE Dreams? The Performance of Companies Issuing Equity Privately." Address correspondence to Clemens Sialm, McCombs School of Business, University of Texas at Austin, 1 University Station B6600, Austin, TX 78712-0217, or e-mail: clemens.sialm@mccombs.utexas.edu.

(c) The Author 2006. Published by Oxford University Press on behalf of The Society for Financial Studies. All rights reserved. For Permissions, please email: journals.permissions@oxfordjournals.org. doi:10.1093/rfs/hhl045 
includes 5244 transactions of private investments in public equity (PIPEs), which raised $\$ 77$ billion between 1995 and 2002. ${ }^{1}$ PIPEs are negotiated with a small number of sophisticated investors. Firms issuing private placements tend to be small, young, and poorly performing companies, where information asymmetries are most severe and market imperfections are most prevalent, as shown by $\mathrm{Wu}$ (2004) and Gomes and Phillips (2005). These frictions may limit the investors interested in providing outside capital to these firms and provide unique opportunities for nontraditional investors.

While public issuances of equity generally result in homogeneous securities, the negotiations between the issuing companies and their investors in private issuances result in highly customized securities. We distinguish between two main security structures: traditional and structured PIPEs. Traditional PIPEs are private placements of conventional common stock and fixed convertibles. On the other hand, structured PIPEs are private placements of securities that include repricing rights, which effectively protect the investors against price declines, as shown by Hillion and Vermaelen (2004). Both securities are generally sold to investors at predetermined discounts. This heterogeneity in the specifications of the securities gives an insight into the preferences and the behavior of the different investor classes.

Hedge funds recently have come under scrutiny because of the perception that their trading activity can increase uncertainty in the market. Hedge funds are subject to limited government oversight and they tend to follow flexible and sophisticated investment strategies involving short-selling and derivative instruments. ${ }^{2}$ These transactions enable them to partially immunize their portfolios against potential price declines. For example, hedge funds can purchase restricted PIPE securities at discounts directly from the companies and simultaneously short-sell the underlying securities of the issuing companies. Hedge funds might therefore be more willing to invest in companies affected by severe information asymmetries or in companies that are temporarily over-valued.

We find that hedge funds tend to invest in companies with weaker fundamentals and higher asymmetric information and take steps to reduce the risk associated with these investments. First, hedge funds are much

\footnotetext{
${ }^{1}$ Other studies on private placements include Wruck (1989); Hertzel and Smith (1993); Hertzel, Lemmon, Linck, and Rees (2002); Hillion and Vermaelen (2004); Wu (2004); Krishnamurthy, Spindt, Subramaniam, and Woidtke (2005); Wu, Wang, and Yao (2005); Chou, Gombola, and Liu (2004); Barclay, Holderness, and Sheehan (2005); Chaplinsky and Haushalter (2005); Gomes and Phillips (2005); Meidan (2005); and Wruck and $\mathrm{Wu}(2005)$.

2 Other papers discussing the behavior and performance of hedge funds include Fung and Hsieh (1997, 1999, 2000a, 2000b, 2001); Ackermann, McEnally, and Ravenscraft (1999); Brown, Goetzmann, and Ibbotson (1999); Brown, Goetzmann, and Park (2000, 2001); Liang (2000); Brown and Goetzmann (2003); Brunnermeier and Nagel (2004); Agarwal and Naik (2004); Gupta and Liang (2005); Fung, Hsieh, Naik, and Ramadorai (2006); and Jagannathan, Malakhov, and Novikov (2006).
} 
more likely than other investors to participate in price-protected structured PIPEs. In our sample, hedge funds account for $72 \%$ of the investments in structured PIPEs and just $16 \%$ of the investments in traditional PIPEs. This behavior indicates that hedge funds have a desire to reduce their risk exposure. We also find that hedge funds are more likely to negotiate price-protected structured PIPEs when investing in companies that are short-sale constrained and that have relatively few institutional holders. Second, companies that sell their equity to hedge funds are forced to sell their securities at significantly higher discounts than companies that sell their equity to other investors, indicating that hedge-funded companies have more difficulty raising equity capital. Third, we observe that the short interest of companies issuing their securities to hedge funds increases around the time of the closing of the deal. If hedge funds are able to effectively reduce their risk exposure, they may be more willing to be investors of last resort. This is in sharp contrast to other investors, such as mutual and pension funds, where regulatory requirements or self-imposed trading restrictions limit the use of such strategies and the purchasing of nontraditional securities.

Our main result demonstrates that there is a strong association between investors and the long-term performance of the funded companies. We find a significant difference in performance between companies financed by hedge funds and companies financed by other investors. For example, the common stocks of companies issuing traditional PIPEs purchased by hedge funds decline by $19.25 \%$ during the first year following the private placement, while the common stocks of companies issuing traditional PIPEs purchased by other investors decline by just $0.35 \%$ during the first year.

Although companies obtaining funding from hedge funds perform relatively poorly, we find that hedge funds that invest in PIPE securities perform relatively well. PIPE securities can be profitable for hedge funds because they obtain equity securities at significant discounts, because they protect themselves through embedded repricing rights and short positions, and because they can liquidate the securities after a relatively short time period. Our evidence is consistent with the hypothesis that hedge funds act as investors of last resort for firms with the fewest alternative financing options. The persistent activity of hedge funds in the PIPE market and the relatively strong performance of hedge funds involved in PIPE transactions indicate that being an investor of last resort pays off.

Our paper is related to the literature analyzing the performance of companies issuing private placements. Since the seminal paper by Wruck (1989), there has been significant interest in analyzing the performance of companies issuing private placements. Wruck (1989) shows that the announcement of a private sale of equity is accompanied by a positive abnormal return, because of improved monitoring by active investors. 
More recently, Hertzel, Lemmon, Linck, and Rees (2002) study the longterm performance of companies issuing private placements and find the puzzling result that positive announcement period returns are followed by abnormally low stock price returns during the next three years. Hillion and Vermaelen (2004) show that companies issuing floating-rate convertibles, a type of structured PIPE, tend to perform particularly poorly in the long term. They suggest that such floating-priced convertibles encourage short-selling by convertible holders and the resulting dilution triggers a permanent decline in the share price. They also find evidence that these structured securities are a source of last resort financing. In a contemporaneous paper, Chaplinsky and Haushalter (2005) investigate the motivations and the returns to firms and investors using both priceprotected and unprotected PIPE securities. They argue that PIPE securities enable companies barred from traditional capital markets to obtain much needed financing. Our paper shows that hedge funds play a crucial role in such transactions: the poor performance of companies issuing traditional PIPEs is concentrated among hedge fund investors and hedge funds account for the vast majority of funding for structured PIPEs.

Our paper is also related to several recent papers that study the crosssectional variation in the performance of firms issuing private placements. Krishnamurthy, Spindt, Subramaniam, and Woidtke (2005) document that the long-term underperformance is concentrated among companies that sell equity to unaffiliated investors. Barclay, Holderness, and Sheehan (2005) show that most of the investors remain passive and that companies obtaining funding from passive investors perform worse. Their results support the entrenchment hypothesis, which says that management places stock with friendly investors that will remain passive. In a recent paper Wruck and $\mathrm{Wu}$ (2005) demonstrate that higher-quality firms are more likely to transact with related investors than with outside investors. Our paper is the first to investigate the role of hedge funds in private placements. Moreover, our paper analyzes a range of security designs, which gives important insights into the behavior and the preferences of different investors.

The remainder of the paper is structured as follows: In Section 1, we give a general overview of PIPE securities. Section 2 describes our data sources and studies the characteristics of the companies that obtain funding from different sources. Section 3 analyzes the impact of the security structure and the investor composition on the short- and long-term stock price performance. Section 4 investigates in detail the short-selling of the common stocks of PIPE issuing companies. Section 5 investigates the performance of hedge funds investing in PIPE securities and Section 6 provides a brief conclusion. 


\section{Security structures}

The specific characteristics of each PIPE transaction are negotiated between the investors and the issuing companies, resulting in numerous different equity-linked security structures. We distinguish between two basic security structures: traditional and structured PIPEs.

\subsection{Traditional PIPEs}

Traditional PIPEs are private placements where the securities are sold at a predetermined price and include common stock, fixed convertible preferred stock, and fixed convertible debt. In a common stock PIPE a fixed number of shares are issued and sold at a predetermined discount to the market price. As shown in the first column of Figure 1, the future value of the investor's position increases proportionally with the stock price. Thus, investors in common stock PIPEs are exposed to future stock price declines because they generally cannot dispose of their shares immediately. However, they can hedge their risk by shorting the underlying stocks. In this case, investors can capture the discount while eliminating their risk exposure.

Another basic traditional security is a fixed convertible security. Fixed convertibles yield a current return through interest or dividend payments and can be converted into a fixed number of shares of the company's common stock at a predetermined conversion ratio, as shown in the second column of Figure 1. If the future stock price is above the conversion price, then the value of a convertible security is proportional to the value of the common stock; otherwise, the PIPE security is not converted into common stock. This inherent protection against decreases in equity prices can partially mitigate the concerns of investors regarding asymmetric information. However, the value of a position in a fixed convertible can still fall below the principal value of the embedded bond security because the company might default. Many hedge funds follow convertible arbitrage strategies by purchasing a fixed convertible security and at the same time dynamically hedging the risk exposure.

\subsection{Structured PIPEs}

Structured PIPEs are equity-based securities, where the investor can convert the PIPE security into a variable number of common stocks during the conversion period. A basic structured PIPE is a variable convertible, where the conversion price is based on market prices of the common stock during a fixed time period following the issuance. This feature protects the investor if the price of the common stock decreases after the PIPE deal is closed, since the investor will receive a larger number of shares following a decrease in the stock price. For example, a basic variable convertible states that the convertible security can be redeemed for common stock with a fixed value $V$ on the conversion date. Thus, if the stock price during the 

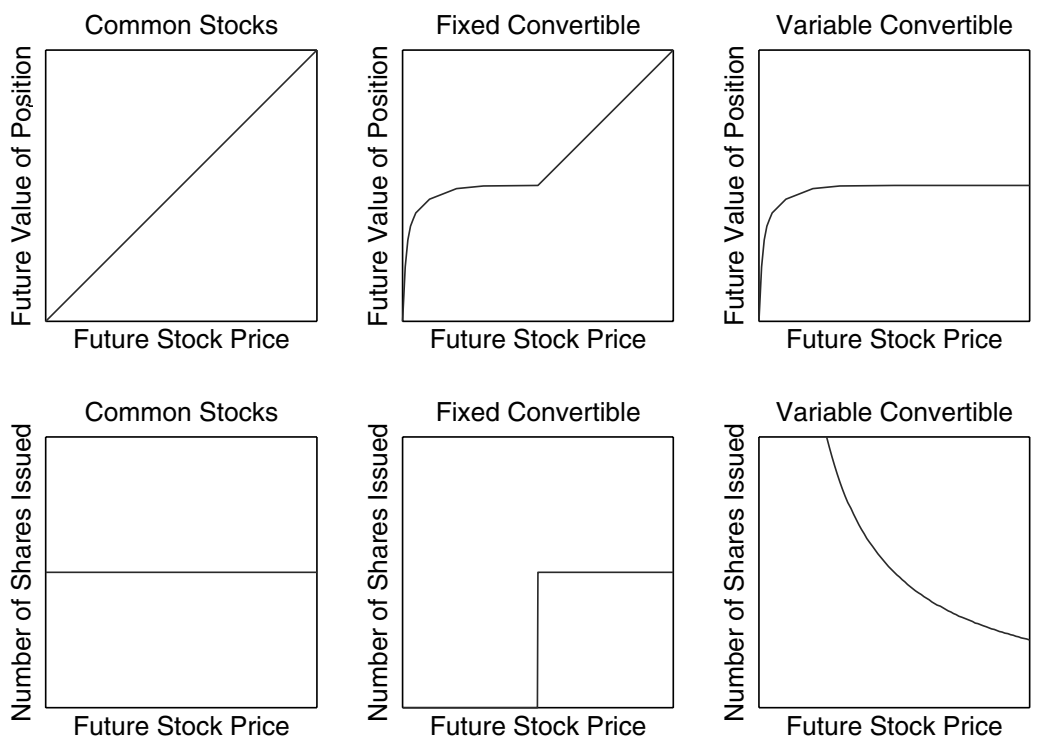

Figure 1

Basic security structures in PIPE transactions

We depict the valuation diagrams and the number of shares issued in three basic PIPE securities: common stocks, fixed convertibles, and variable convertibles.

future conversion period is $p$, then the company would issue $V / p$ shares to the owner of the variable convertible. Thus, the value of the investor's position in a variable convertible would equal $V$, as long as the total value of the equity of the firm is sufficiently large. Decreasing stock prices will result in a greater number of shares issued and in a greater dilution of existing shareholders, as shown in the third column of Figure 1. Variable convertibles often include caps and floors that limit the possible range of conversion prices.

This variable security is essentially "adverse-selection-proof" equity [Stein (1992)], because all parties in the transaction can agree that this security has a fixed value of $V$ on the conversion date-assuming the firm does not declare bankruptcy before the maturity date of the security. Repricing rights are similar to an embedded short position, which immunizes the investors from changes in the price of the underlying stock after the PIPE issuance.

Though structured PIPEs theoretically may be an ideal source of financing for firms with a high degree of asymmetric information, arguments also have been made that these contracts are faulty and leave the issuing firm prey to market manipulation. As described by Hillion and Vermaelen (2004), by short-selling the underlying equity shares during the conversion period, PIPE investors might be able temporarily to depress stock prices, 
resulting in a more favorable conversion ratio. In such an instance, variable PIPE investors would receive a larger number of undervalued common stocks through the convertible security, and this excessive dilution would permanently reduce the stock value for the original stockholders.

\section{Data}

Our data set on PIPE transactions was provided by Sagient Research. The data includes detailed information on the characteristics of PIPE transactions and their investors. All the information from Sagient Research comes directly from Securities and Exchange Commission (SEC) filings and public announcements made by the companies. Our data set includes 5244 PIPE transactions between 1995 and 2002. ${ }^{3}$ To obtain accounting and stock price measures of companies issuing PIPEs, we match our PIPE data set with the Center for Research in Security Prices (CRSP)/Compustat databases using the ticker symbols and the names of the issuing companies. Of the 5244 PIPE transactions, 914 companies cannot be matched to CRSP primarily because they are not traded on one of the major exchanges. However, these unmatched transactions raise less than $5 \%$ of the total proceeds of PIPE transactions.

\subsection{Summary statistics}

Panel A of Table 1 summarizes the characteristics of the PIPE securities issued between 1995 and 2002. These 5244 PIPE deals raised a total of $\$ 77$ billion. Many companies are involved in multiple PIPE transactions. While 1560 companies issue exactly one PIPE, 1134 companies issue more than one PIPE. The total number of firms obtaining PIPE financing (2694 different firms) is very similar to the number of firms obtaining financing through Seasoned Equity Offerings (SEOs) (2637 different firms) over our sample period. However, the total proceeds from PIPEs ( $\$ 77$ billion) are considerably smaller than the proceeds from SEOs ( $\$ 498$ billion). The importance of PIPEs has increased gradually between 1995 and 2002. The proceeds of PIPEs equaled $6.9 \%$ of the SEO proceeds in the first four years and $21.1 \%$ in the last four years of our sample.

Traditional PIPEs account for the majority of proceeds raised through PIPE transactions. The 3585 traditional PIPEs raised $\$ 65$ billion and the 1659 structured deals raised $\$ 12$ billion. The composition of these deals has changed considerably over time. Whereas structured PIPEs accounted for $53.0 \%$ of the PIPE transactions between 1995 and 1998, structured

\footnotetext{
${ }^{3}$ We exclude 95 Reg S placements and 469 144-A placements. Regulation S placements are purchased by foreign institutional investors and have become less prevalent because of changes to SEC regulations. 144-A placements are issued by larger and more mature companies and are not considered PIPEs because of different regulatory treatments. Our qualitative results are not affected if we include the Reg $\mathrm{S}$ and the 144-A transactions.
} 
Table 1

Summary statistics

Panel A: Characteristics of PIPE transactions

\begin{tabular}{lccc}
\hline & All PIPEs & $\begin{array}{c}\text { Traditional } \\
\text { PIPEs }\end{array}$ & $\begin{array}{c}\text { Structured } \\
\text { PIPEs }\end{array}$ \\
\hline Number of transactions & 5244 & 3585 & 1659 \\
Total capital raised (in millions) & 76,871 & 65,240 & 11,631 \\
Mean capital raised (in millions) & 14.66 & 18.20 & 7.01 \\
Median capital raised (in millions) & 4.50 & 5.00 & 3.30 \\
Mean capital raised to market value (\%) & 20.92 & 22.84 & 16.76 \\
Median capital raised to market value (\%) & 9.93 & 10.81 & 8.54 \\
Mean number of investors per deal & 4.45 & 5.02 & 3.23 \\
Median number of investors per deal & 1 & 2 & 1 \\
\hline
\end{tabular}

Panel B: Proportion of capital raised by various known investor classes (\%)

\begin{tabular}{lccc}
\hline & All PIPEs & $\begin{array}{c}\text { Traditional } \\
\text { PIPEs }\end{array}$ & $\begin{array}{c}\text { Structured } \\
\text { PIPEs }\end{array}$ \\
\hline Hedge funds & 24.45 & 15.58 & 71.86 \\
Corporations & 17.29 & 19.60 & 4.92 \\
Mutual funds and institutional advisors & 16.99 & 19.69 & 2.58 \\
Venture capital & 11.79 & 12.93 & 5.71 \\
Buyout firm and private equity & 11.55 & 13.57 & 0.71 \\
Various individual investors & 6.18 & 6.48 & 4.60 \\
Brokers and dealers & 6.08 & 6.11 & 5.88 \\
Banks & 2.19 & 2.10 & 2.67 \\
Insurance companies & 2.02 & 2.25 & 0.81 \\
Pension funds & 0.91 & 1.06 & 0.09 \\
Charitable, educational, and family trusts & 0.55 & 0.62 & 0.18 \\
\hline
\end{tabular}

Panel C: Proportion of capital raised by industry composition (\%)

\begin{tabular}{|c|c|c|c|}
\hline & All PIPEs & $\begin{array}{l}\text { Traditional } \\
\text { PIPEs }\end{array}$ & $\begin{array}{l}\text { Structured } \\
\text { PIPEs }\end{array}$ \\
\hline Communications & 37.16 & 37.47 & 35.46 \\
\hline Healthcare & 20.20 & 19.86 & 22.13 \\
\hline Consumer cyclical & 9.79 & 10.46 & 6.03 \\
\hline Technology & 8.60 & 7.40 & 15.27 \\
\hline Industrial & 7.31 & 7.23 & 7.77 \\
\hline Financial & 7.19 & 7.92 & 3.09 \\
\hline Energy & 3.33 & 3.46 & 2.65 \\
\hline Consumer noncyclicals & 2.83 & 2.39 & 5.27 \\
\hline Utilities & 2.31 & 2.57 & 0.86 \\
\hline Basic materials & 1.18 & 1.18 & 1.21 \\
\hline Diversified & 0.09 & 0.06 & 0.27 \\
\hline
\end{tabular}

0.06 ( 0.09

The table summarizes the characteristics of PIPE transactions by security structure (traditional vs. structured).

PIPEs accounted for just $24.4 \%$ of the PIPE transactions between 1999 and 2002. ${ }^{4}$ The PIPE transactions increase the funds available for companies substantially: the average ratio of the proceeds of a PIPE and the market

\footnotetext{
${ }^{4}$ According to Sagient Research, the number of traditional PIPEs has continued to grow after 2002, exceeding 1000 deals per year in 2004 and 2005. On the other hand, the number of structured PIPEs decreased to 72 deals in 2003 and recovered subsequently to 193 and 322 deals in 2004 and 2005 , respectively.
} 
capitalization of the company exceeds $20 \%$. The number of investors per deal ranges between one and 84 , with most PIPE transactions having only one investor.

Panel B of Table 1 summarizes the composition of the investors in PIPE securities. Sagient Research groups the 12,042 PIPE investors into 11 different classes. The investors can be identified for more than $80 \%$ of the capital raised in our sample. Hedge funds are the largest investor class, accounting for $24.45 \%$ of the total investments in PIPE securities by identified investors. Corporations, mutual funds, venture capital, and private equity funds also are important investors in this market and account for more than $10 \%$ of capital raised. Individual investors, who are often executives [as shown by Wruck and $\mathrm{Wu}(2005)$ ], account for just $6.18 \%$ of the total investments in PIPE securities. However, individual investors often are involved in PIPE securities as minority partners, contributing less than $50 \%$ of the total proceeds.

The investor composition differs dramatically between the two basic security structures. Hedge funds account for $15.58 \%$ of the investments in traditional PIPEs and for $71.86 \%$ of the investments in structured PIPEs with known investor classifications. The remaining investors in structured PIPEs are dispersed across several investor classes. Thus, we find a very strong clientele effect for the two security structures, showing that hedge funds are associated with securities that protect against price declines.

Sagient Research also categorizes the companies issuing PIPEs into 11 industries listed in Panel C. Most companies issuing PIPEs are in high-tech industries, such as communications, healthcare, and technology.

\subsection{Characteristics of PIPE securities}

The detailed specification of PIPE securities is customized to the needs of the investors and the issuing companies. Thus, we should expect the detailed contract provisions to differ among the various investor classes. Table 2 summarizes the characteristics of PIPE transactions by the two investor classes (hedge funds vs. other investors) and by the security structure (traditional vs. structured). PIPE transactions are allocated to "Hedge Funds" if hedge funds account for more than $50 \%$ of the total proceeds and to "Other Investors" if other known investors account for more than $50 \%$. For some deals, we do not know the identity of the investor or the investor classification. Therefore, we cannot allocate all PIPE transactions to the two investor classes considered here. ${ }^{5}$ We find that hedge funds are majority investors in

\footnotetext{
5 We do not include deals with unknown or unclassified investor classes in the category "Other Investors" because these investors also might be hedge funds. Hedge funds might be more likely to be unknown or unclassified than other investor classes such as corporations, mutual funds, brokers, banks, or insurance companies because hedge funds generally are not as well known as these other investor classes, which are in direct contact with retail investors and customers.
} 
Table 2

Characteristics of PIPE transactions

All PIPEs Traditional PIPEs Structured PIPEs

\begin{tabular}{|c|c|c|c|c|c|c|}
\hline & $\begin{array}{l}\text { Hedge } \\
\text { Funds }\end{array}$ & $\begin{array}{l}\text { Other } \\
\text { Investors }\end{array}$ & $\begin{array}{l}\text { Hedge } \\
\text { Funds }\end{array}$ & $\begin{array}{l}\text { Other } \\
\text { Investors }\end{array}$ & $\begin{array}{l}\text { Hedge } \\
\text { Funds }\end{array}$ & $\begin{array}{l}\text { Other } \\
\text { Investors }\end{array}$ \\
\hline Number of observations & 1367 & 1818 & 586 & 1559 & 781 & 259 \\
\hline $\begin{array}{r}\text { Capital raised } \\
\text { (in millions) }\end{array}$ & 9.17 & 25.21 & 10.60 & 27.96 & 8.09 & 8.66 \\
\hline $\begin{array}{l}\text { Capital raised to market } \\
\text { capitalization }(\%)\end{array}$ & 12.27 & 21.79 & 13.58 & 22.74 & 11.29 & 16.08 \\
\hline $\begin{array}{l}\text { Discount for common } \\
\text { stocks }(\%)\end{array}$ & 14.12 & 9.02 & 14.12 & 9.02 & & \\
\hline $\begin{array}{l}\text { Discount for variable } \\
\text { convertibles }(\%)\end{array}$ & 16.86 & 17.59 & & & 16.86 & 17.59 \\
\hline $\begin{array}{l}\text { Fraction of deals with } \\
\text { warrants }(\%)\end{array}$ & 49.59 & 29.40 & 46.47 & 28.14 & 51.94 & 36.96 \\
\hline $\begin{array}{l}\text { Relative value of the } \\
\text { warrants }(\%)\end{array}$ & 17.19 & 13.04 & 19.56 & 12.61 & 15.40 & 15.67 \\
\hline $\begin{array}{l}\text { Term for convertible } \\
\text { securities (in months) }\end{array}$ & 35.95 & 55.55 & 43.80 & 63.83 & 34.56 & 39.88 \\
\hline $\begin{array}{l}\text { Days to first conversion for } \\
\text { convertible securities }\end{array}$ & 33.02 & 43.71 & 15.13 & 32.78 & 38.36 & 72.31 \\
\hline
\end{tabular}

The table summarizes the characteristics of PIPE transactions by investor type (hedge funds vs. other investors) and by security structure (traditional vs. structured). PIPE transactions are allocated to "Hedge Funds" if hedge funds account for more than $50 \%$ of the investment and to "Other Investors" if other known investors account for more than $50 \%$ of the investment. We test for the differences between the two investor classes (hedge funds vs. other investors) using a $t$-test for the means taking into account clustering by firm. The pairs that are significantly different at the $10 \%$ significance level are indicated in italics.

$26.5 \%$ of traditional PIPEs with known investors and they are majority investors for $74.6 \%$ of structured PIPEs. The table summarizes the means of various characteristics. To determine whether there is a statistical difference in the characteristics between the two investor groups, we test for the differences using a $t$-test for the means taking into account clustering by individual firms. The pairs, where the means are significantly different from each other at the 10\% significance level, are indicated in italics.

Companies obtaining financing from hedge funds tend to obtain significantly smaller investments than other companies, indicating that investors might be unwilling to take a large stake in such companies. The average hedge-funded PIPE raises $\$ 9.17$ million or $12.27 \%$ of market capitalization, while the average non-hedge-funded PIPE raises $\$ 25.21$ million or $21.79 \%$ of market capitalization.

Investors in PIPEs are often induced to participate in these deals because of favorable contract specifications, which include significant discounts and valuable warrants. We compute the discount of common stocks as the difference between the market price and the purchase price divided by the market price. The discount of variable convertibles does not need to be computed since it is already included in the specifications of the 
contract. ${ }^{6}$ The Black-Scholes values of the warrants are computed by Sagient research using the historical standard deviation over the month prior to the close.

The total costs associated with issuing PIPEs can be very significant. Companies issuing common stock PIPEs to hedge funds accept an average discount of $14.12 \%$, whereas companies issuing common stock PIPEs to other investors accept an average discount of only $9.02 \%{ }^{7}$ The discounts on variable convertibles are also substantial. In addition, a significant fraction of PIPE transactions include warrants, which effectively increase the discount of the securities. We find that hedge-funded PIPEs are significantly more likely to include warrants. The average value of the warrants included in private placements is substantial and is estimated at $14.82 \%$ of the proceeds of PIPEs. These significant discounts offered to hedge funds are consistent with our conjecture that these firms are not able to raise capital from other investors or through other means.

\subsection{Characteristics of PIPE companies}

Table 3 summarizes some characteristics of firms issuing PIPEs prior to the issuance of their PIPE transactions. Panel A reports stock market measures, and Panel B reports accounting measures.

Companies issuing PIPEs tend to be relatively young and small. ${ }^{8} \mathrm{Com}-$ panies obtaining financing from hedge funds are significantly smaller than companies obtaining financing from other identified investors. Hedgefunded companies exhibit significantly higher standard deviations and higher betas based on the Capital Asset Pricing Model (CAPM) during the year prior to the PIPE issuance compared to other PIPE companies. Furthermore, companies issuing structured PIPEs to hedge funds have significantly less analyst coverage than companies issuing traditional PIPEs. ${ }^{9}$ Since the number of analysts following a security is often used as a proxy for asymmetric information, this difference confirms our view that companies issuing structured PIPEs are potentially more subject to

\footnotetext{
${ }^{6}$ We can compute the discounts for common stock PIPEs and for variable convertibles, but we cannot compute the discount of fixed convertibles since we do not have sufficient information on the security features to compute a reliable value of the convertible bonds.

7 Meidan (2005) analyzes the determinants of the discounts in detail and shows that discounts have an important role in explaining long-term performance.

${ }^{8}$ For each company we determine the age relative to the first listing in the CRSP database.

${ }^{9}$ We obtain the number of analysts making earnings per share (EPS) forecasts for PIPE companies 3 months prior to the PIPE issuance from I/B/E/S. See Brennan and Subrahmanyam (1995); Aboody and Lev (2000); and Wu (2004). Diether, Malloy, and Scherbina (2002) show that the dispersion of the earnings forecasts by analysts is a measure of asymmetric information. We also find that companies issuing structured PIPEs have a significantly higher dispersion of earnings forecasts than companies issuing traditional PIPEs. However, we do not use this alternative proxy of asymmetric information, since this dispersion information often is not available for our sample of PIPE companies because $79.6 \%$ of PIPE companies have no or only one analyst following their earnings.
} 
Table 3

Characteristics of PIPE companies

Panel A: Stock market characteristics of PIPE companies

\begin{tabular}{|c|c|c|c|c|c|c|}
\hline & \multicolumn{2}{|c|}{ All PIPEs } & \multicolumn{2}{|c|}{ Traditional PIPEs } & \multicolumn{2}{|c|}{ Structured PIPEs } \\
\hline & $\begin{array}{l}\text { Hedge } \\
\text { Funds }\end{array}$ & $\begin{array}{l}\text { Other } \\
\text { Investors }\end{array}$ & $\begin{array}{l}\text { Hedge } \\
\text { Funds }\end{array}$ & $\begin{array}{l}\text { Other } \\
\text { Investors }\end{array}$ & $\begin{array}{l}\text { Hedge } \\
\text { Funds }\end{array}$ & $\begin{array}{l}\text { Other } \\
\text { Investors }\end{array}$ \\
\hline Number of observations & 1367 & 1818 & 586 & 1559 & 781 & 259 \\
\hline $\begin{array}{l}\text { Market capitalization } \\
\text { (in millions) }\end{array}$ & 151.86 & 301.67 & 176.81 & 328.58 & 133.14 & 139.71 \\
\hline $\begin{array}{l}\text { Stock return in year prior to } \\
\text { close }(\%)\end{array}$ & 41.91 & 31.61 & 41.84 & 31.28 & 41.96 & 33.48 \\
\hline $\begin{array}{l}\text { Standard deviation in year prior } \\
\text { to close }(\%)\end{array}$ & 118.98 & 101.38 & 118.45 & 101.90 & 119.43 & 98.32 \\
\hline $\begin{array}{l}\text { CAPM-beta in year } \\
\text { prior to close }\end{array}$ & 2.00 & 1.73 & 1.93 & 1.76 & 2.05 & 1.59 \\
\hline $\begin{array}{l}\text { Volume six months prior to } \\
\text { close }(\%)\end{array}$ & 253.73 & 151.54 & 229.79 & 146.16 & 273.71 & 183.30 \\
\hline $\begin{array}{l}\text { Proportion of institutional } \\
\text { holdings }(\%)\end{array}$ & 16.22 & 19.77 & 21.98 & 21.29 & 11.73 & 10.73 \\
\hline $\begin{array}{l}\text { Short interest six months prior } \\
\text { to close }(\%)\end{array}$ & 2.61 & 2.00 & 2.61 & 1.96 & 2.61 & 2.23 \\
\hline $\begin{array}{l}\text { Number of } \\
\text { analysts }\end{array}$ & 1.24 & 1.60 & 1.68 & 1.70 & 0.91 & 0.99 \\
\hline $\begin{array}{l}\text { Venture capital backed for } \\
\text { recent IPOs }(\%)\end{array}$ & 22.75 & 27.72 & 27.47 & 28.67 & 19.21 & 22.01 \\
\hline Age (years) & 7.08 & 6.62 & 7.62 & 6.66 & 6.66 & 6.40 \\
\hline
\end{tabular}

Panel B: Accounting characteristics of PIPE companies

\begin{tabular}{|c|c|c|c|c|c|c|}
\hline & \multicolumn{2}{|c|}{ All PIPEs } & \multicolumn{2}{|c|}{ Traditional PIPEs } & \multicolumn{2}{|c|}{ Structured PIPEs } \\
\hline & $\begin{array}{l}\text { Hedge } \\
\text { Funds }\end{array}$ & $\begin{array}{l}\text { Other } \\
\text { Investors }\end{array}$ & $\begin{array}{l}\text { Hedge } \\
\text { Funds }\end{array}$ & $\begin{array}{l}\text { Other } \\
\text { Investors }\end{array}$ & $\begin{array}{l}\text { Hedge } \\
\text { Funds }\end{array}$ & $\begin{array}{l}\text { Other } \\
\text { Investors }\end{array}$ \\
\hline Number of observations & 1260 & 1688 & 565 & 1457 & 695 & 231 \\
\hline Assets (in millions) & 104.80 & 233.13 & 132.81 & 257.93 & 82.02 & 76.73 \\
\hline Book-to-market ratio (\%) & 33.44 & 45.61 & 35.22 & 48.42 & 31.97 & 28.03 \\
\hline Leverage $(\%)$ & 56.00 & 60.77 & 54.99 & 61.36 & 56.82 & 57.08 \\
\hline Positive return on assets ( $\%)$ & 11.89 & 16.55 & 15.48 & 17.48 & 8.97 & 10.57 \\
\hline Return on assets $(\%)$ & -63.42 & -61.06 & -64.85 & -60.15 & -62.26 & -66.85 \\
\hline $\begin{array}{l}\text { Capital expenses and } \mathrm{R} \& \mathrm{D} \\
\text { relative to assets }(\%)\end{array}$ & 33.34 & 32.54 & 36.79 & 32.29 & 30.54 & 34.09 \\
\hline
\end{tabular}

The table summarizes the characteristics of the firms that issue PIPE transactions by investor type (hedge funds vs. other investors) and by security structure (traditional vs. structured). PIPE transactions are allocated to "Hedge Funds" if hedge funds account for more than $50 \%$ of the investment and to "Other Investors" if other known investors account for more than $50 \%$ of the investment. Panel A summarizes stock market measures of PIPE companies. Panel B compares accounting variables of PIPE companies. We test for the differences between the two investor classes (hedge funds vs. other investors) using a $t$-test for the means taking into account clustering by firm. The pairs that are significantly different at the $10 \%$ significance level are indicated in italics.

information asymmetries and might have more difficulties in raising capital publicly.

Although companies obtaining financing from hedge funds tend to be significantly smaller, they exhibit higher trading volumes and higher short interest positions 6 months prior to the close of the PIPE transaction 
than other companies. ${ }^{10}$ This relationship might be caused by the fact that hedge funds prefer to purchase securities of companies that are more liquidly traded since they often pursue more aggressive trading strategies involving short-sales and dynamic trading.

Companies obtaining funding through structured PIPEs tend to have significantly smaller institutional holdings than companies obtaining funding through traditional PIPEs. ${ }^{11}$ Whereas large institutions hold $21.49 \%$ of the common shares of companies issuing traditional PIPEs, they hold only $11.47 \%$ of the companies issuing structured PIPEs. D'Avolio (2002) shows that the main suppliers of stock loans are institutional investors and that stocks with low institutional holdings are more expensive to borrow. ${ }^{12}$ This evidence justifies why hedge funds are more likely to negotiate price-protected securities whenever firms are short-sale constrained.

Brav and Gompers (1997) show that venture capital backing adds value even after the initial public offering. In our sample, $25.7 \%$ of the PIPE companies that went public during the 5 years prior to the PIPE issuance are venture-backed, according to the Securities Data Corporation (SDC). Companies that obtain funding from hedge funds are significantly less likely to be venture-backed, indicating that venture backing also has an impact on the opportunities to raise funds subsequent to the IPO.

Panel B reports several accounting measures during the fiscal year prior to the issuance of the PIPE transactions ${ }^{13}$ Companies obtaining financing through structured PIPEs and hedge funds tend to have relatively smaller asset values and book values. Companies in our sample experience poor operating performance during the fiscal year prior to their issuance of a PIPE. The return on assets for the average company issuing a PIPE is $-62.8 \%$, and only $14.6 \%$ of companies issuing PIPEs have positive returns on assets. Furthermore, companies obtaining funding from hedge funds are even less likely to be profitable than companies obtaining funding from other investors.

Companies issuing PIPEs make substantial capital expenditures and research and development investments despite their poor operating performance. We do not find that companies obtaining funds from hedge funds have significantly different capital expenditures and research and

\footnotetext{
10 The monthly short positions of stocks listed on NYSE, AMEX, and NASDAQ are obtained directly from the respective stock exchanges.

${ }^{11}$ We obtain the CDA/Spectrum Institutional 13(f) common stock holdings from Thompson Financial.

12 See Asquith, Pathak, and Ritter (2005); and Nagel (2005) for additional evidence of the interaction between institutional holdings and short-selling.

13 The data are obtained from Compustat. We give the exact definitions of the accounting variables in Appendix C. All the accounting measures are winsorized at the $1 \%$ level to eliminate the impact of extreme outliers.
} 
development investments. These companies need to raise external funds to maintain their investment levels.

The dismal operating performance may pose difficulties in raising capital through public debt markets and secondary equity offerings. According to SDC, just $0.20 \%$ of PIPE companies issue public debt and $3.2 \%$ of PIPE companies make secondary equity offerings in the year of their PIPE transactions. This supports our earlier contention that firms that issue PIPEs are limited, because of their size and recent poor performance, in their abilities to raise financing in the more conventional public debt and equity markets. These firms must resort to PIPE securities and hedge funds to be able to maintain their investment levels and to avoid more severe financial distress. ${ }^{14}$

Our results on the characteristics of firms that sell PIPEs show that hedge funds are more likely to invest in smaller, riskier firms with high asymmetric information. Traditional investors are reluctant to take a large undiversified position in such companies. Hedge funds, however, are able to act as investors of last resort because they can offset the risk by shortselling the underlying securities or by holding nontraditional protected securities.

\section{Stock price performance}

This section studies the short- and long-term stock performance of companies that issue PIPEs. The stock return analysis estimates the returns that original shareholders of common stocks would have experienced had they held their stocks for several years post issuance. The return of these original investors will, in general, be different from the return of the new investors who purchase the PIPEs.

Figure 2 depicts the average daily buy-and-hold return relatives 250 trading days before and 500 trading days after the closing. ${ }^{15}$ The PIPE companies are divided into four groups according to the security structure (traditional vs. structured) and according to the investor classification (hedge funds and other investors). ${ }^{16}$ Consistent with Hertzel, Lemmon, Linck, and Rees (2002), we find a negative relation between short- and long-term returns for traditional PIPEs. Though PIPE issuing companies

\footnotetext{
14 The cost of information production as it relates to the decision to sell equity privately versus publicly is explored in Chemmanur and Fulghieri (1999); and Habib and Johnsen (2000).

15 The buy-and-hold return relatives are normalized to one on the closing day. The buy-and-hold return relatives are defined as: $R R_{i, t}=\prod_{s=0}^{t}\left(1+R_{i, s}\right)$, where $R_{i, s}$ is the daily rate of return of stock $i$ at time $s$.

${ }^{16}$ The abnormal returns in the second year after the PIPE issues include only a portion of the abnormal returns for PIPE issuances in 2002, because we only have available stock return data until December 2003. The results do not change qualitatively if we only analyze the PIPE deals issued between 1995 and 2001, which have complete return series.
} 

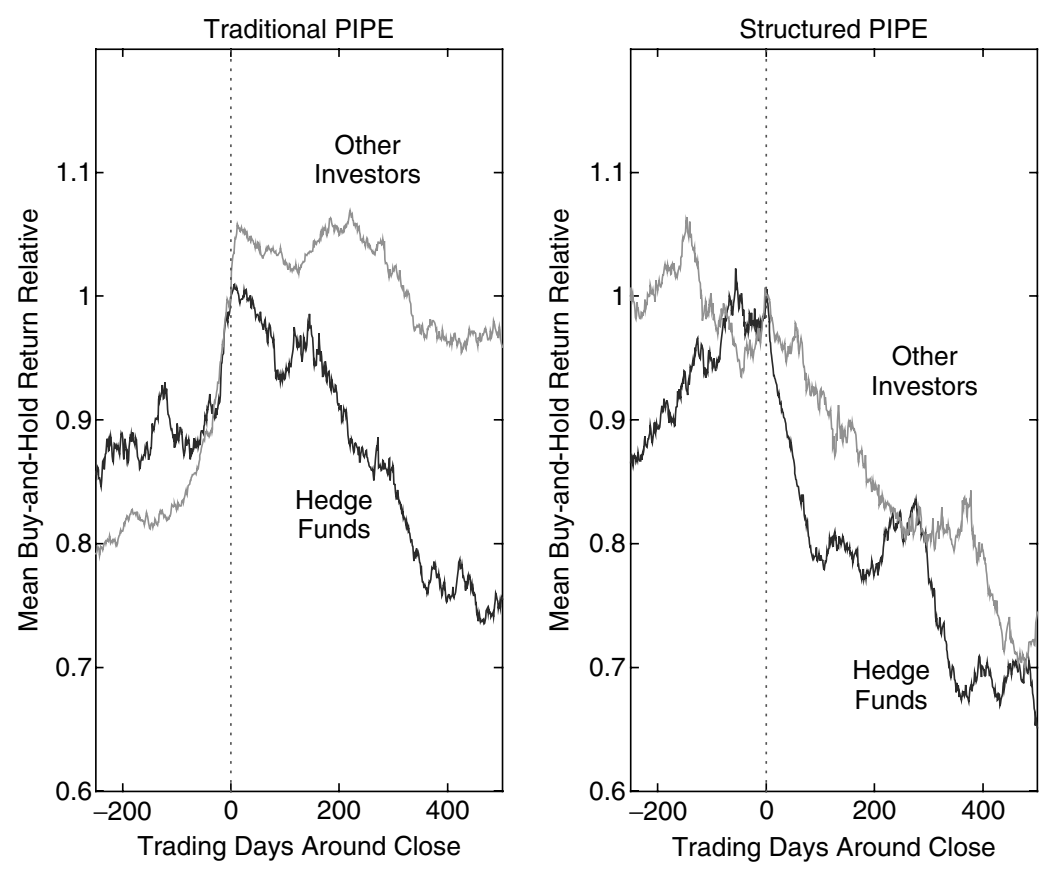

Figure 2

Performance of companies issuing PIPEs by security type

The figure depicts the average buy-and-hold return relatives of companies that issue PIPEs by security structure (traditional vs. structured) and by investor (hedge funds vs. other investors). PIPE transactions are allocated to "Hedge Funds" if hedge funds account for more than $50 \%$ of the investment and to "Other Investors" if other known investors account for more than $50 \%$ of the investment. The return relatives are normalized to 1 on the issue dates of the PIPEs.

experience, on average, a positive short-term announcement performance, they experience a negative long-term performance. We find the stock price performance differs dramatically between the two investor classes. Companies issuing traditional PIPEs to hedge funds perform significantly worse than companies that issue traditional PIPEs to other investors. For structured PIPE companies, we find a significant decline in the market value for both investor classifications. The results for the structured PIPEs are similar to the ones reported by Hillion and Vermaelen (2004), who study floating convertible PIPEs issued between January 1995 and August 1998. The remainder of this section tests the robustness of these results using different risk adjustments.

\subsection{Short-term stock price performance}

The performance of stock prices of PIPE companies for different time windows is summarized in Panels A (raw buy-and-hold returns) and B (abnormal returns relative to the benchmark) of Table 4. We follow Barber and Lyon (1997) and benchmark performance by using a single control firm 
for each PIPE firm. We match each company in our sample to a comparable company according to its industry, market capitalization, book-to-market ratio, and momentum characteristics in the previous month, as described in more detail in Appendix B. ${ }^{17}$

Companies issuing PIPEs to non-hedge investors experience a strong positive return during a 10-day event window around the close of the PIPE transaction (first row labeled $[-4,5]$ ), whereas companies issuing PIPEs to hedge investors experience no significant positive return during the announcement period. This result is partially due to the fact that hedge funds are more likely to participate in structured PIPEs, which tend to have lower announcement effects. We also find that stock prices start to move prior to the closing date of the PIPE, which indicates that some market participants have prior information about the transactions.

\subsection{Long-term stock price performance}

Table 4 divides the long-term performance of the stock returns after the PIPE issuance into three different time periods: [6, 100], [6, 250], and $[6,500]$. We observe in the first column of Panel B that companies issuing PIPEs to hedge funds tend to underperform the matched companies by $31.40 \%$ over the two years after the PIPE issuance. Over the same time period, the underperformance of non-hedge funded companies is just $13.33 \% .{ }^{18}$ A long-term underperformance is consistent with the prior literature on private placements and also can be found for initial public offerings and for SEOs. ${ }^{19} \mathrm{We}$ also find that companies issuing structured PIPEs perform significantly worse in the long term than companies issuing traditional PIPEs. The dismal performance of these companies justifies the earlier observation that these firms offer securities with repricing rights to enable investors to protect themselves against price declines.

We also find performance differences between hedge-funded and nonhedge funded companies after conditioning on the security structure. Companies issuing traditional PIPEs to hedge funds underperform their benchmarks by $19.53 \%$ in the two years following the PIPE issue. However, companies obtaining traditional financing from other investors do not underperform their benchmarks sufficiently to generate statistically significant results. On the other hand, the abnormal returns do not differ significantly between the two investor classifications for structured

${ }^{17}$ We also compute results using alternative benchmarks (e.g., market return; the appropriate size and book-to-market matched portfolio by Fama and French; industry and size matched firms; industry, size, and book-to-market matched firms; and SEO-matched firms). The results are not significantly different using these alternative benchmarks and are not reported because of space constraints.

${ }^{18}$ Choosing nonoverlapping time periods does not qualitatively affect the results. For example, hedge-funded companies experience abnormal returns of $-12.51 \%$ during $[101,250]$ and $-12.75 \%$ during $[251,500]$, whereas non-hedge funded companies experience excess returns of $-8.75 \%$ during $[101,250]$ and $-6.69 \%$ during $[251,500]$.

${ }^{19}$ See, for example: Spiess and Affleck-Graves (1995); and Loughran and Ritter (1995, 1997). 
Table 4

Returns to common stocks of companies that issue PIPEs

Panel A: Raw buy-and-hold returns

\begin{tabular}{|c|c|c|c|c|c|c|}
\hline & \multicolumn{2}{|c|}{ All PIPEs } & \multicolumn{2}{|c|}{ Traditional PIPEs } & \multicolumn{2}{|c|}{ Structured PIPEs } \\
\hline & $\begin{array}{l}\text { Hedge } \\
\text { Funds }\end{array}$ & $\begin{array}{l}\text { Other } \\
\text { Investors }\end{array}$ & $\begin{array}{l}\text { Hedge } \\
\text { Funds }\end{array}$ & $\begin{array}{l}\text { Other } \\
\text { Investors }\end{array}$ & $\begin{array}{l}\text { Hedge } \\
\text { Funds }\end{array}$ & $\begin{array}{l}\text { Other } \\
\text { Investors }\end{array}$ \\
\hline $\begin{array}{l}\text { Observations with } \\
\text { available data }\end{array}$ & 1242 & 1609 & 553 & 1370 & 689 & 239 \\
\hline $\begin{array}{l}\text { Announcement- } \\
\text { term }[-4,5]\end{array}$ & $\begin{array}{c}1.22 \\
(0.81)\end{array}$ & $\begin{array}{l}6.95^{* * *} \\
(0.77)\end{array}$ & $\begin{array}{l}3.60^{* * *} \\
(1.13)\end{array}$ & $\begin{array}{l}7.71^{* * *} \\
(0.85)\end{array}$ & $\begin{array}{c}-0.68 \\
(1.15)\end{array}$ & $\begin{array}{r}2.59 \\
(1.67)\end{array}$ \\
\hline $\begin{array}{l}\text { Short-term } \\
{[6,100]}\end{array}$ & $\begin{array}{l}-14.68^{* * *} \\
(2.15)\end{array}$ & $\begin{array}{l}-2.21 \\
(1.89)\end{array}$ & $\begin{array}{l}-7.48^{* *} \\
(3.65)\end{array}$ & $\begin{array}{l}-0.94 \\
(2.09)\end{array}$ & $\begin{array}{l}-20.45^{* * *} \\
(2.48)\end{array}$ & $\begin{array}{l}-9.47^{* *} \\
(4.24)\end{array}$ \\
\hline $\begin{array}{l}\text { Medium-term } \\
{[6,250]}\end{array}$ & $\begin{array}{l}-19.25^{* * *} \\
(3.61)\end{array}$ & $\begin{array}{l}-0.35 \\
(3.71)\end{array}$ & $\begin{array}{l}-14.29^{* * *} \\
(4.93)\end{array}$ & $\begin{array}{c}2.29 \\
(4.19)\end{array}$ & $\begin{array}{l}-23.22^{* * *} \\
(4.86)\end{array}$ & $\begin{array}{c}-15.47^{* *} \\
(6.39)\end{array}$ \\
\hline $\begin{array}{l}\text { Long-term } \\
{[6,500]}\end{array}$ & $\begin{array}{l}-31.70^{* * *} \\
(4.13)\end{array}$ & $\begin{array}{l}-8.77^{*} \\
(5.03)\end{array}$ & $\begin{array}{l}-27.39^{* * *} \\
(5.49)\end{array}$ & $\begin{array}{l}-6.21 \\
(5.64)\end{array}$ & $\begin{array}{l}-34.42^{* * *} \\
(5.66)\end{array}$ & $\begin{array}{c}-21.65^{* *} \\
(8.83)\end{array}$ \\
\hline \multicolumn{7}{|c|}{ Panel B: Excess buy-and-hold returns relative to matched companies } \\
\hline & \multicolumn{2}{|c|}{ All PIPEs } & \multicolumn{2}{|c|}{ Traditional PIPEs } & \multicolumn{2}{|c|}{ Structured PIPEs } \\
\hline & $\begin{array}{l}\text { Hedge } \\
\text { Funds }\end{array}$ & $\begin{array}{l}\text { Other } \\
\text { Investors }\end{array}$ & $\begin{array}{l}\text { Hedge } \\
\text { Funds }\end{array}$ & $\begin{array}{l}\text { Other } \\
\text { Investors }\end{array}$ & $\begin{array}{l}\text { Hedge } \\
\text { Funds }\end{array}$ & $\begin{array}{l}\text { Other } \\
\text { Investors }\end{array}$ \\
\hline $\begin{array}{l}\text { Observations with } \\
\text { available data }\end{array}$ & 1242 & 1609 & 553 & 1370 & 689 & 239 \\
\hline $\begin{array}{l}\text { Announcement- } \\
\text { term }[-4,5]\end{array}$ & $\begin{array}{r}1.40 \\
(0.93)\end{array}$ & $\begin{array}{l}5.74^{* * *} \\
(0.88)\end{array}$ & $\begin{array}{l}3.70^{* * *} \\
(1.24)\end{array}$ & $\begin{array}{l}6.29^{* * *} \\
(0.98)\end{array}$ & $\begin{array}{c}-0.44 \\
(1.34)\end{array}$ & $\begin{array}{c}2.58 \\
(1.85)\end{array}$ \\
\hline $\begin{array}{l}\text { Short-term } \\
{[6,100]}\end{array}$ & $\begin{array}{l}-10.85^{* * *} \\
(2.57)\end{array}$ & $\begin{array}{r}-4.02^{*} \\
(2.16)\end{array}$ & $\begin{array}{r}-4.97 \\
(4.20)\end{array}$ & $\begin{array}{c}-1.68 \\
(2.32)\end{array}$ & $\begin{array}{l}-15.57^{* * *} \\
(3.02)\end{array}$ & $\begin{array}{l}-17.43^{* * *} \\
(5.01)\end{array}$ \\
\hline $\begin{array}{l}\text { Medium-term } \\
{[6,250]}\end{array}$ & $\begin{array}{l}-18.06^{* * *} \\
(3.94)\end{array}$ & $\begin{array}{c}-7.49^{*} \\
(4.18)\end{array}$ & $\begin{array}{c}-11.07^{* *} \\
(5.47)\end{array}$ & $\begin{array}{l}-2.64 \\
(4.42)\end{array}$ & $\begin{array}{l}-23.67^{* * *} \\
(5.33)\end{array}$ & $\begin{array}{l}-35.27^{* * *} \\
(12.15)\end{array}$ \\
\hline $\begin{array}{l}\text { Long-term } \\
{[6,500]}\end{array}$ & $\begin{array}{l}-31.40^{* * * *} \\
(5.88)\end{array}$ & $\begin{array}{r}-13.33^{*} \\
(7.03)\end{array}$ & $\begin{array}{c}-19.53^{* * *} \\
(7.00)\end{array}$ & $\begin{array}{c}-7.88 \\
(7.90)\end{array}$ & $\begin{array}{c}-38.87^{* * * *} \\
(8.21)\end{array}$ & $\begin{array}{l}-40.65^{* * *} \\
(12.35)\end{array}$ \\
\hline
\end{tabular}

The table summarizes the mean raw and abnormal returns for companies issuing PIPEs by investor type (hedge funds vs. other investors) and by security structure (traditional vs. structured). The buy-and-hold returns are computed over four different time periods measured in trading days around the close of the PIPE transaction $([-4,5],[6,100],[6,250],[6,500])$. PIPE transactions are allocated to "Hedge Funds" if hedge funds account for more than $50 \%$ of the investment and to "Other Investors" if other known investors account for more than $50 \%$ of the investment. Abnormal returns are computed by subtracting the raw return for companies matched in the month prior to the PIPE deal according to industry, size, book-to-market ratio, and momentum from the return of PIPE companies. The returns are expressed in percent. The standard errors for the means are reported in parentheses and are corrected for clustering by firm. The significance levels for each individual raw and abnormal return are denoted by '*', '**', and '***' and indicate whether the results are statistically different from zero at the 10,5 , and $1 \%$ significance levels. We test for the differences between the two investor classes (hedge funds vs. other investors) using a $t$-test for the means taking into account clustering by firm. The pairs that are significantly different at the $10 \%$ significance level are indicated in italics.

PIPEs. This insignificant result is caused by the relatively small number of structured PIPEs by "Other Investors" and by the fact that the composition of the "Other Investors" differs between traditional and structured PIPEs. For example, regulated mutual funds account for a large fraction of traditional PIPEs and for a very small fraction of structured PIPEs, as 
shown in Table 1. Moreover, brokers and dealers, who, like hedge funds, are unregulated and can make use of sophisticated trading strategies, account for a relatively large fraction of structured PIPEs.

Companies issuing structured PIPEs and companies obtaining funding from hedge funds experience a substantial deterioration of their stock valuations over the two years considered here. These abnormal returns are economically and statistically highly significant. The underperformance of companies issuing traditional PIPEs to non-hedge investors is less pronounced, particularly during the first year following the PIPE issuance. The statistical inference is not affected much if the standard errors are estimated using bootstrap-simulations following Lyon, Barber, and Tsai (1999). ${ }^{20}$

In unreported results, we also analyze the short- and the long-term performance of PIPE companies using a more detailed definition of PIPE securities and using additional investor categories. Our results remain consistent using these alternative classifications. ${ }^{21}$

The poor performance of companies issuing structured PIPEs is consistent with the manipulation hypothesis of Hillion and Vermaelen (2004). However, the poor performance of companies issuing traditional PIPEs to hedge funds cannot be explained by market manipulation, because investors in traditional PIPEs cannot increase the value of their position through short-selling pressure during the conversion period. Instead, we argue that hedge funds are investors of last resort for troubled firms. At the time of the closing of the PIPE, the market may not have been fully aware of the troubled state of the issuing firm. Subsequently, as the market becomes informed, prices decline. The relatively slow market adjustment can be justified by the fact that companies often do not identify immediately the investors in their private placements. Furthermore, these firms are very small with little analyst coverage, which might cause an additional delay in the market reaction. Hedge funds are ideally suited to be investors of last resort as they have few restrictions in establishing short positions to hedge any possible downside risk associated with investing in troubled firms, as described in Section 4.

\subsection{Calendar time portfolios}

In this section, we compute calendar time abnormal returns of companies that issue PIPEs. Fama (1998) and Mitchell and Stafford (2000) argue that the event study methodology does not appropriately take into account

\footnotetext{
${ }^{20}$ A relatively large number of companies issue multiple PIPEs over our sample period. Thus, the returns of these companies are weighted more heavily. However, our results are not affected significantly if we exclude multiple deals. Moreover, our results do not change qualitatively if we exclude companies with stock prices below $\$ 5$ on the closing day of the transaction or if we exclude companies with market capitalizations below $\$ 10$ million. See Ball, Kothari, and Shanken (1995) for a discussion of potential problems caused by low-price stocks.

${ }^{21}$ Appendix A summarizes the detailed security structures.
} 
cross-sectional dependencies in returns. In a first step, we form a buy-andhold portfolio of all the common stocks of companies that issue PIPEs during the past 500 trading days between 1996 and 2002. ${ }^{22}$ In a second step, we compute the abnormal returns using various factor models. The equally weighted portfolio invests $\$ 1$ in each PIPE issuing company the day after the close of the PIPE transaction. Thus, the portfolio holds each position for 500 days.

Because of the low liquidity in some of the companies issuing PIPEs, daily closing prices often are stale. Therefore, we analyze the weekly instead of daily returns and additionally include lagged factor returns. ${ }^{23}$ We compute abnormal returns using several different factor models. The first model simply computes the average excess return relative to the market return. ${ }^{24}$ The second model estimates the abnormal return using the one-factor CAPM. The third model follows Fama and French (1993) and includes a market, size, and book-to-market factor. The fourth model adds a momentum factor following Carhart (1997). The fifth model follows the conditional model of Ferson and Schadt (1996) and uses predetermined instruments to capture time-varying factor loadings. Our specification includes interaction terms between the Carhart factor returns and various demeaned lagged macro-economic variables. ${ }^{25}$ We obtain similar results if we use a conditional model based on a one- or a three-factor model. The sixth model is based on the factor model by Eckbo, Masulis, and Norli (2000) and includes six macro factors, which control for event-dependent risk characteristics. ${ }^{26}$ Eckbo, Masulis, and Norli (2000), Carlson, Fisher, and Giammarino (2006), and Lyandres, Sun, and Zhang (2006) argue

${ }^{22}$ The results are consistent if we only include companies that issued PIPEs in the last 100 or 250 trading days.

${ }^{23}$ We obtain similar results if we use daily returns and if we do not include the lagged factor returns. Actually, the standard errors tend to be lower with daily returns.

${ }^{24}$ The daily factor returns for the three-factor model are obtained from Kenneth French's Web site: http://mba.tuck.dartmouth.edu/pages/faculty/ken.french/Data_Library. The daily momentum return is constructed following the description on French's website.

25 The macro variables of Ferson and Schadt (1996) are the one-month Treasury bill yield, the dividend yield of the CRSP value-weighted index, the Treasury yield spread (10-year minus 1-year Treasury bond yields), the quality spread in the corporate bond market (AAA minus BAA corporate bond yields), and a January indicator variable.

${ }^{26}$ The macro factors of Eckbo, Masulis, and Norli (2000) are the value-weighted market index, the return spread between Treasury bonds with 10-year and 1-year maturities, the return spread between 90 and 30-day Treasury bills, the seasonally adjusted percent change in real per capita consumption of nondurable goods, the difference in the monthly yield change on BAA- and AAA-rated corporate bonds, and unexpected inflation. The Treasury and corporate bond yields are obtained from the Web site of the Board of Governors of the Federal Reserve System: http://www.federalreserve.gov/releases/. The Treasury bill yields are obtained from CRSP. Per capita nondurable consumption is obtained from the NIPA accounts of the Bureau of Economic Analysis (http://www.bea.doc.gov), and the consumer price inflation is obtained from the Bureau of Labor Statistics (http://www.bls.gov/cpi/). The estimation of expected inflation follows Eckbo, Masulis, and Norli (2000) by running a regression of real Treasury bill returns on a constant and 12 of its lagged values. We regress the portfolio returns on the original raw factor series, as reported in Panel D from Table 9 of Eckbo, Masulis, and Norli (2000). 
Table 5

Returns of calendar time portfolios of companies that issue PIPEs

All PIPEs

Traditional PIPEs

Structured PIPEs

\begin{tabular}{|c|c|c|c|c|c|c|}
\hline & $\begin{array}{l}\text { Hedge } \\
\text { Funds }\end{array}$ & $\begin{array}{l}\text { Other } \\
\text { Investors }\end{array}$ & $\begin{array}{l}\text { Hedge } \\
\text { Funds }\end{array}$ & $\begin{array}{l}\text { Other } \\
\text { Investors }\end{array}$ & $\begin{array}{l}\text { Hedge } \\
\text { Funds }\end{array}$ & $\begin{array}{l}\text { Other } \\
\text { Investors }\end{array}$ \\
\hline $\begin{array}{l}\text { Excess return } \\
\text { above market }\end{array}$ & $\begin{array}{l}-32.37^{* * *} \\
(11.62)\end{array}$ & $\begin{array}{r}-11.83 \\
(9.97)\end{array}$ & $\begin{array}{c}-16.50 \\
(12.45)\end{array}$ & $\begin{array}{l}-7.24 \\
(10.05)\end{array}$ & $\begin{array}{l}-42.03^{* * *} \\
(12.16)\end{array}$ & $\begin{array}{r}-24.49^{*} \\
(12.59)\end{array}$ \\
\hline CAPM alpha & $\begin{array}{l}-35.85^{* * *} \\
(10.91)\end{array}$ & $\begin{array}{r}-14.86 \\
(9.39)\end{array}$ & $\begin{array}{r}-19.77^{*} \\
(11.77)\end{array}$ & $\begin{array}{c}-9.90 \\
(9.49)\end{array}$ & $\begin{array}{l}-45.99^{* * *} \\
(11.47)\end{array}$ & $\begin{array}{l}-28.69^{* *} \\
(12.04)\end{array}$ \\
\hline $\begin{array}{l}\text { 3-Factor Fama- } \\
\text { French alpha }\end{array}$ & $\begin{array}{l}-29.78^{* * *} \\
(7.19)\end{array}$ & $\begin{array}{r}-10.52^{*} \\
(5.91)\end{array}$ & $\begin{array}{r}-13.99^{*} \\
(8.22)\end{array}$ & $\begin{array}{c}-5.71 \\
(6.15)\end{array}$ & $\begin{array}{c}-39.99^{* * *} \\
(8.58)\end{array}$ & $\begin{array}{c}-24.81^{* *} \\
(10.00)\end{array}$ \\
\hline $\begin{array}{l}\text { 4-Factor Carhart } \\
\text { alpha }\end{array}$ & $\begin{array}{l}-27.54^{* * *} \\
(7.35)\end{array}$ & $\begin{array}{r}-11.22^{*} \\
(6.02)\end{array}$ & $\begin{array}{r}-14.44^{*} \\
(8.42)\end{array}$ & $\begin{array}{c}-6.71 \\
(5.87)\end{array}$ & $\begin{array}{l}-36.05^{* * *} \\
(8.74)\end{array}$ & $\begin{array}{l}-22.64^{* *} \\
(10.23)\end{array}$ \\
\hline $\begin{array}{l}\text { 4-Factor Ferson- } \\
\text { Schadt alpha }\end{array}$ & $\begin{array}{l}-29.61^{* * *} \\
(7.15)\end{array}$ & $\begin{array}{c}-13.23^{* *} \\
(5.87)\end{array}$ & $\begin{array}{r}-16.53^{*} \\
(8.51)\end{array}$ & $\begin{array}{c}-8.84 \\
(6.10)\end{array}$ & $\begin{array}{c}-37.07^{* * *} \\
(8.59)\end{array}$ & $\begin{array}{c}-24.91^{* *} \\
(10.61)\end{array}$ \\
\hline $\begin{array}{l}\text { 6-Factor Eckbo- } \\
\quad \text { Masulis-Norli alpha }\end{array}$ & $\begin{array}{l}-35.43^{* * *} \\
(10.76)\end{array}$ & $\begin{array}{r}-14.51 \\
(9.27)\end{array}$ & $\begin{array}{r}-19.41^{*} \\
(11.72)\end{array}$ & $\begin{array}{c}-9.56 \\
(9.40)\end{array}$ & $\begin{array}{l}-45.51^{* * *} \\
(11.28)\end{array}$ & $\begin{array}{l}-28.39^{* *} \\
(11.84)\end{array}$ \\
\hline
\end{tabular}

The table summarizes the abnormal returns of a calendar-time portfolios that include all the stocks of companies, which closed a PIPE deal during the last 500 trading days. The portfolios are formed by investor type (hedge funds vs. other investors) and by security structure (traditional vs. structured). PIPE transactions are allocated to "Hedge Funds" if hedge funds account for more than 50\% of the investment and to "Other Investors" if other known investors account for more than $50 \%$ of the investment. We compute abnormal returns according to several factor models as summarized in the first column. The abnormal returns are expressed in percent and are annualized. The standard errors are summarized in parentheses. '*', '**', and '***' denote abnormal returns that are statistically different from zero at the 10,5 , and $1 \%$ significance levels. We test for the differences between the characteristics of traditional and structured PIPEs and for the two investor classes (hedge funds vs. other investors) by computing the intercept of the factor regressions using the difference in the raw returns of the two portfolios as the dependent variable. The pairs that are significantly different at the $10 \%$ significance level are indicated in italics.

that the risk exposure changes around SEOs. Such risk changes might explain the underperformance of the issuing companies relative to matched companies. $^{27}$

Table 5 summarizes the annualized abnormal returns for various portfolios of PIPE issuing companies, according to the investor composition and the security structure. The first row shows that a portfolio including all the stocks that issue PIPEs to hedge funds during the previous 2 years has an average annualized excess return of $-32.37 \%$ per year relative to the market. On the other hand, a corresponding portfolio of companies obtaining financing from other investors does not exhibit a significantly negative excess return.

The calendar time portfolios confirm our previous results that companies issuing structured PIPEs and companies raising capital from hedge fund investors perform poorly. Thus, our results are not driven by common

${ }^{27}$ We do not find large changes in risk for our sample of PIPE companies during the two years following the PIPE issuances. Whereas the standard deviation of the returns decreases slightly during the two years after a PIPE issuance, the beta does not decrease. Furthermore, risk levels would need to change dramatically to explain the dismal returns of PIPE issuing companies. 
variation in risk levels and risk premia or by changes of the fundamentals of the companies, which result from equity issuances.

\subsection{Determinants of stock price performance}

This section analyzes whether our results are robust if we include additional control variables in a multivariate regression specification. The dependent variable is the excess buy-and-hold return of a PIPE issuing company relative to one of the six Fama-French size and book-to-market portfolios. The independent variables are indicator variables for the security structure and the investor composition and additional firm and deal characteristics. All the accounting variables are winsorized at the $1 \%$ level to eliminate the impact of extreme outliers. The standard errors are robust and corrected for clustering of observations by the same company. All estimations include unreported year- and industry-fixed effects.

The first three columns of Table 6 summarize the results over the 10-day event window. We find that companies obtaining financing from hedge funds perform substantially worse in the short-term even after controlling for the security structure. Moreover, the results indicate that companies issuing structured PIPEs also perform significantly worse than companies receiving funding from other investor classes.

The remaining columns summarize the regression results using the long-term excess returns over two different time periods $([6,250]$, and $[6,500])$ as the dependent variables. The indicator variables for hedge fund investors and for structured PIPEs enter significantly and confirm the previous results. These results are not affected substantially if we control for additional variables. Companies with larger market capitalizations experience larger underperformance than smaller companies. An important determinant of stock price performance is the indicator variable for whether a company recently received venture capital funding. Companies that are venture capital backed outperform companies that are not venture capital backed by a substantial margin.

\subsection{Additional measures of long-term performance}

We find that companies receiving funding from hedge funds are more likely to be delisted within two years of the PIPE issuance. For example, in the two years following the PIPE issuance, $34.6 \%$ of companies receiving funding from hedge funds and $25.6 \%$ of companies receiving funding from other known investors are delisted. Looking at the delisting codes in CRSP indicates that the vast majority of companies are delisted because they do not satisfy the listing requirements (e.g., price fell below acceptable level; 


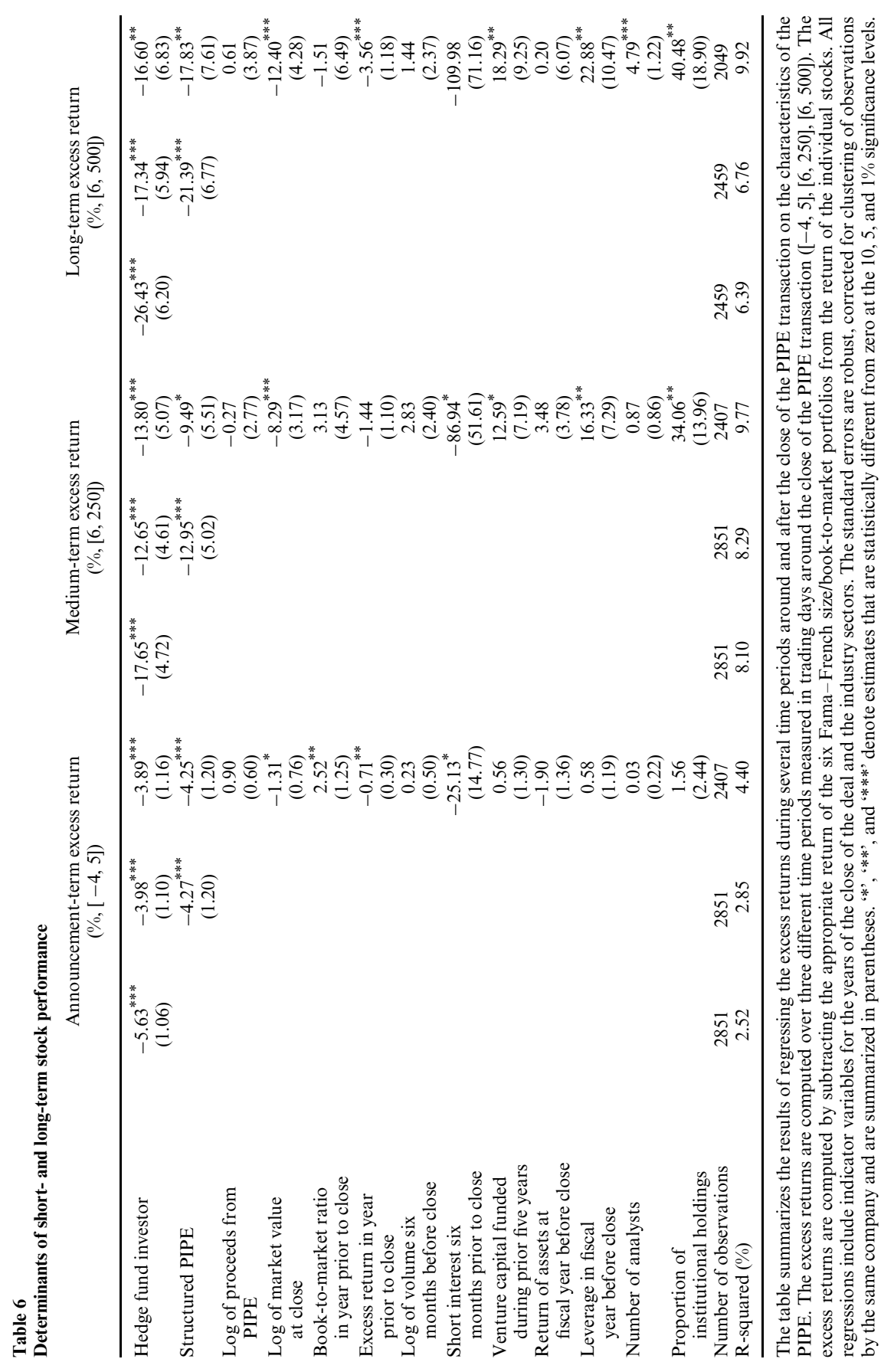


violations of exchange's financial guidelines; insufficient float or assets). Only $15 \%$ of delisted companies merged with other companies. ${ }^{28}$

In unreported results, we analyze whether there is a relationship between the investor composition and the accounting performance. Consistent with the stock market performance, we find that companies obtaining financing from hedge funds and through structured PIPEs tend to experience worse operating performance after the PIPE issuance.

We do not argue that the poor long-term performance is caused by the involvement of hedge funds. It is possible that many of the companies that obtain funding from hedge funds might not have been able to attract other investors and would have performed even worse without the hedge fund investment, since many of these companies might have been forced into default or more acute financial distress.

The poor long-term performance of hedge-funded companies is consistent with worse fundamentals and with more difficulty in obtaining financing from other more conservative investors. Hedge funds act as investors of last resort for firms with the fewest alternative financing options. Hedge funds often are more willing to invest in companies with substantial asymmetric information or in companies that are temporarily over-valued, because they are able to hedge the downside risk by either negotiating PIPE securities with repricing rights or by entering into short positions of the underlying stocks of the issuing companies. This is in sharp contrast to other investors, such as mutual and pension funds, for whom regulatory requirements or self-imposed trading restrictions limit the use of such strategies.

\section{Short interest of PIPE companies}

This section investigates whether short-selling pressure is associated with hedge fund investors. Hedge fund investors often use short-selling or derivative securities. Other investors are more likely to be buy-and-hold investors because of regulatory requirements or a lack of knowledge and experience using sophisticated trading strategies.

Investors might be interested in hedging their risk exposure of PIPE securities through short-selling because they might have anticipated that these firms would perform poorly in the long term. The incentives to hedge tend to be larger for traditional PIPEs than for structured PIPEs because

\footnotetext{
${ }^{28}$ Delisted companies are included in our stock performance analysis. We use the actual daily returns until the delisting date and the delisting return from CRSP on the last trading date. The returns of delisted companies in the event study are replaced by the returns of the matched company after being delisted to avoid missing observations. In the calendar time portfolios, the portfolios are rebalanced on the delisting date. Shumway (1997) documents a bias in CRSP because correct delisting returns are often not available. He finds that this effect biases returns upward for delists owing to bankruptcy and other negative reasons. In our case, this effect would bias against our results since companies obtaining financing from hedge funds and through structured PIPEs are more likely to be delisted.
} 
structured PIPEs are already partially protected against price declines. Hillion and Vermaelen (2004) argue that a structured PIPE might give its investors incentives to manipulate the price downward in order to receive a higher percentage of the firm upon conversion. One way to reduce the effective price temporarily is to short-sell the stocks aggressively during the conversion window. In this case, we should observe a significant increase in the short interest for companies that issue structured PIPEs.

To investigate the short-selling behavior around the closing date of the PIPE securities, we compute the average ratio between securities shorted in a specific month and the total number of securities outstanding for firms surrounding the PIPE transaction. Unfortunately, we do not observe the identity of the short-sellers. Thus, we do not know whether short-selling is driven by the investors in the deals or by unaffiliated short-sellers. Also, if investors are attempting to manipulate a security, they have an incentive to hide their actions, making it more difficult for us to find an effect.

Figure 3 reports the abnormal short interest of companies issuing traditional and structured PIPEs for hedge fund and non-hedge fund investors. Abnormal short interest is defined as the difference between the short interest of companies issuing PIPEs and the short interest of matched companies according to industry, size, book-to-market, and momentum, as described in Section 3. We find that traditional PIPE companies that obtain financing from hedge funds have significantly higher initial levels and significantly larger increases in their short interest around PIPE issuances. This result is consistent with hedge funds' eliminating their risk exposure after investments in PIPE securities by taking short positions in the underlying stocks. In unreported results we find that the increase in the short interest is larger for common stock than for fixed convertible PIPEs. This should be expected since the optimal hedge ratio is substantially larger for common stock than for fixed convertible securities, as discussed in Section 1. Moreover, we find that the abnormal short interest of traditional PIPE companies that obtain financing from hedge funds decreases gradually within the first two years after the PIPE issuances. This result is consistent with hedge funds closing out their short positions as they dispose of the stocks acquired through their original PIPE purchase. ${ }^{29}$

For structured PIPEs, we find that the short interest increases for transactions done by both hedge and non-hedge fund investors. However, the change in short interest for hedge fund deals is not significantly

\footnotetext{
29 The short interest of companies issuing traditional PIPEs to hedge funds increases on average by $0.9 \%$ of the shares outstanding. On the other hand, the median hedge fund investment for these deals is $6.6 \%$ of the market capitalization. It should not be expected that the short interest increases by the whole amount of the proceeds. First, investors might hedge using derivative securities or using off-shore markets. Second, a significant portion of traditional PIPEs is fixed convertible securities, which have an optimal hedge ratio of less than $100 \%$. Third, it might be difficult to short-sell some less liquid securities. We find that the increase in short-selling is concentrated in a small number of companies, which have relatively high institutional holdings.
} 

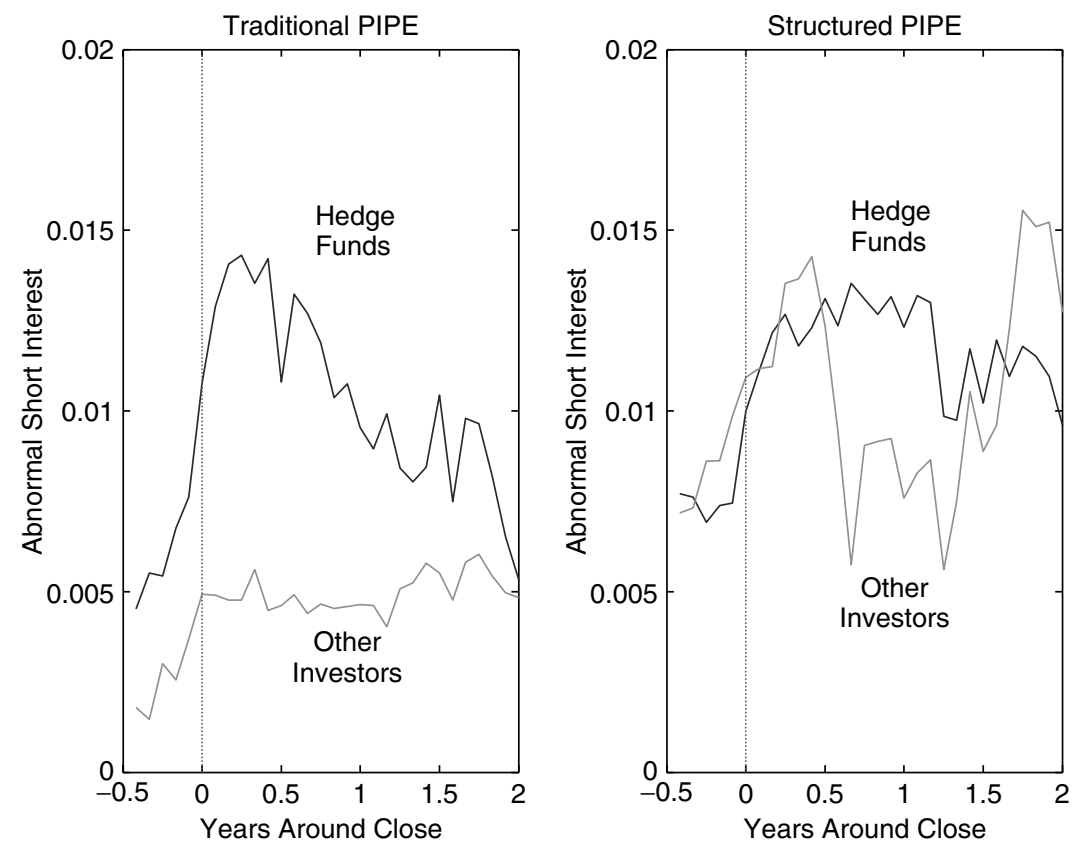

Figure 3

Abnormal short interest companies issuing PIPEs

We depict the abnormal short interest of companies issuing PIPEs by security structure (traditional vs structured) and investor (hedge funds vs. other investors). Short interest is defined as the proportion of shares sold short relative to shares outstanding. Abnormal short interest is the difference between the short interest of companies issuing PIPEs and the short interest of matched companies according to industry, size, book-to-market, and momentum. PIPE transactions are allocated to "Hedge Funds" if hedge funds account for more than $50 \%$ of the investment and to "Other Investors" if other known investors account for more than $50 \%$ of the investment.

different from the change in short interest for other deals. This can be explained by the fact that "Other Investors" for structured PIPEs often are brokers and dealers, who might follow trading strategies similar to those of hedge funds. We find that the increase in short interest is less pronounced for companies issuing structured PIPEs to hedge funds than for companies issuing traditional PIPEs to hedge funds. Furthermore, as discussed in Section 3.5, companies exhibit negative operating performance after issuing structured PIPE securities. The lack of a substantial increase in short interest for companies issuing structured PIPEs and the poor operating performance of these companies are more consistent with the investor of last resort hypothesis than with market manipulation.

Table 7 analyzes the determinants of the short interest after the PIPE issuance using a multivariate regression. Three dependent variables are considered on the basis of the average short interest during the first 6 months, the second 6 months, and the second year after the PIPE issuance. The independent variables include indicator variables for the 
Table 7

Determinants of short interest

\begin{tabular}{|c|c|c|c|c|c|c|}
\hline \multirow[b]{2}{*}{$\begin{array}{l}\text { Traditional PIPE and } \\
\text { hedge fund investor }\end{array}$} & \multicolumn{2}{|c|}{$\begin{array}{l}\text { Short interest during } \\
\text { the first six months } \\
\text { after close }(\%)\end{array}$} & \multicolumn{2}{|c|}{$\begin{array}{l}\text { Short interest during } \\
\text { the second six months } \\
\text { after close }(\%)\end{array}$} & \multicolumn{2}{|c|}{$\begin{array}{c}\text { Short interest during } \\
\text { the second year } \\
\text { after close }(\%)\end{array}$} \\
\hline & $\begin{array}{l}0.79^{* * *} \\
(0.16)\end{array}$ & $\begin{array}{l}0.84^{* * *} \\
(0.16)\end{array}$ & $\begin{array}{l}0.62^{* * *} \\
(0.22)\end{array}$ & $\begin{array}{l}0.69^{* * *} \\
(0.22)\end{array}$ & $\begin{array}{c}0.01 \\
(0.30)\end{array}$ & $\begin{array}{c}0.17 \\
(0.29)\end{array}$ \\
\hline Structured PIPE & $\begin{array}{r}0.39^{*} \\
(0.20)\end{array}$ & $\begin{array}{l}0.64^{* * *} \\
(0.21)\end{array}$ & $\begin{array}{c}0.33 \\
(0.29)\end{array}$ & $\begin{array}{l}0.67^{* *} \\
(0.31)\end{array}$ & $\begin{array}{l}0.47 \\
(0.43)\end{array}$ & $\begin{array}{l}0.97^{* *} \\
(0.44)\end{array}$ \\
\hline $\begin{array}{l}\text { Structured PIPE and } \\
\text { hedge fund investor }\end{array}$ & $\begin{array}{c}0.17 \\
(0.22)\end{array}$ & $\begin{array}{c}0.14 \\
(0.24)\end{array}$ & $\begin{array}{c}0.31 \\
(0.32)\end{array}$ & $\begin{array}{c}0.23 \\
(0.34)\end{array}$ & $\begin{array}{c}-0.28 \\
(0.47)\end{array}$ & $\begin{array}{c}-0.35 \\
(0.47)\end{array}$ \\
\hline $\begin{array}{l}\text { Short interest during the six } \\
\text { months before close }\end{array}$ & $\begin{array}{l}0.86^{* * *} \\
(0.03)\end{array}$ & $\begin{array}{l}0.80^{* * *} \\
(0.03)\end{array}$ & $\begin{array}{l}0.68^{* * *} \\
(0.03)\end{array}$ & $\begin{array}{l}0.60^{* * *} \\
(0.04)\end{array}$ & $\begin{array}{l}0.54^{* * *} \\
(0.05)\end{array}$ & $\begin{array}{l}0.42^{* * *} \\
(0.05)\end{array}$ \\
\hline $\begin{array}{l}\text { Log of proceeds from } \\
\text { PIPE }\end{array}$ & & $\begin{array}{c}0.13^{*} \\
(0.07)\end{array}$ & & $\begin{array}{l}0.20^{* *} \\
(0.10)\end{array}$ & & $\begin{array}{r}0.20^{*} \\
(0.12)\end{array}$ \\
\hline $\begin{array}{l}\text { Log of market value } \\
\text { at close }\end{array}$ & & $\begin{array}{l}0.44^{* * *} \\
(0.08)\end{array}$ & & $\begin{array}{l}0.69^{* * *} \\
(0.12)\end{array}$ & & $\begin{array}{l}0.91^{* * *} \\
(0.16)\end{array}$ \\
\hline $\begin{array}{l}\text { Book-to-market ratio in } \\
\text { year prior to close }\end{array}$ & & $\begin{array}{c}-0.01 \\
(0.10)\end{array}$ & & $\begin{array}{l}0.00 \\
(0.15)\end{array}$ & & $\begin{array}{c}0.30 \\
(0.33)\end{array}$ \\
\hline $\begin{array}{l}\text { Excess return in year } \\
\text { prior to close }\end{array}$ & & $\begin{array}{l}0.12^{* * *} \\
(0.03)\end{array}$ & & $\begin{array}{l}0.13^{* *} \\
(0.05)\end{array}$ & & $\begin{array}{c}0.05 \\
(0.05)\end{array}$ \\
\hline $\begin{array}{l}\text { Log of trading volume } \\
\text { six months before close }\end{array}$ & & $\begin{array}{c}-0.07 \\
(0.05)\end{array}$ & & $\begin{array}{c}-0.15^{* *} \\
(0.07)\end{array}$ & & $\begin{array}{l}-0.22^{* * *} \\
(0.08)\end{array}$ \\
\hline $\begin{array}{l}\text { Venture capital funded } \\
\text { during prior five years }\end{array}$ & & $\begin{array}{l}-0.18 \\
(0.14)\end{array}$ & & $\begin{array}{c}-0.14 \\
(0.21)\end{array}$ & & $\begin{array}{c}-0.23 \\
(0.32)\end{array}$ \\
\hline $\begin{array}{l}\text { Return on assets at } \\
\text { fiscal year before close }\end{array}$ & & $\begin{array}{c}-0.04 \\
(0.09)\end{array}$ & & $\begin{array}{c}0.04 \\
(0.13)\end{array}$ & & $\begin{array}{l}-0.24 \\
(0.22)\end{array}$ \\
\hline $\begin{array}{l}\text { Leverage in fiscal } \\
\text { year before close }\end{array}$ & & $\begin{array}{c}-0.20^{* *} \\
(0.10)\end{array}$ & & $\begin{array}{c}-0.10 \\
(0.14)\end{array}$ & & $\begin{array}{c}-0.01 \\
(0.24)\end{array}$ \\
\hline Number of analysts & & $\begin{array}{c}0.02 \\
(0.03)\end{array}$ & & $\begin{array}{c}0.04 \\
(0.05)\end{array}$ & & $\begin{array}{c}0.09 \\
(0.06)\end{array}$ \\
\hline $\begin{array}{l}\text { Proportion of } \\
\text { institutional holdings }\end{array}$ & & $\begin{array}{c}0.63^{*} \\
(0.38)\end{array}$ & & $\begin{array}{c}0.91 \\
(0.61)\end{array}$ & & $\begin{array}{l}1.96^{* *} \\
(0.97)\end{array}$ \\
\hline Number of observations & 2665 & 2362 & 2379 & 2124 & 1567 & 1414 \\
\hline R-squared (\%) & 63.24 & 67.62 & 39.28 & 44.98 & 23.99 & 33.11 \\
\hline
\end{tabular}

The table summarizes the results of regressing the average short interest during several time periods after the close of the PIPE transaction on the characteristics of the PIPE and firm attributes. All regressions include indicator variables for the years of the close of the deal and the industry sectors. The standard errors are robust and corrected for clustering of observations by the same company and are summarized in parentheses. '*', '**', and '***' denote estimates that are statistically different from zero at the 10,5 , and $1 \%$ significance levels.

security structure and the investor composition, the lagged value of short interest, and additional control variables. All regressions include year- and industry-fixed effects and correct the standard errors for clustering.

The regression results are consistent with Figure 3 and indicate that companies that issue traditional PIPEs to hedge funds have significantly higher short interest during the first year after the issue of a PIPE. Furthermore, we also find that companies that issue structured PIPEs experience an increase in short interest relative to companies that issue PIPEs to non-hedge fund investors. However, the results for the security structure tend to be less significant than the results for the investor classification. 
These results indicate a significant association between short interest and investor classifications. We find that companies that issue traditional PIPEs to hedge funds and companies that issue structured securities experience a significant increase in short interest after the PIPE issuance. This result supports our hypothesis that hedge funds are an investor of last resort. Hedge funds are willing to invest in poorly performing companies because they are able to protect themselves either by obtaining price-protected structured PIPEs or by short-selling the underlying stocks.

\section{Performance of hedge funds that invest in PIPEs}

Although the performance of the underlying stocks of companies obtaining funding from hedge funds is very poor, it is not necessarily the case that the PIPE investors also perform poorly. Unfortunately, we cannot compute the returns investors generate in specific deals for several reasons: first, we do not know when the investors exercise their conversion rights and liquidate their positions. ${ }^{30}$ Second, we do not observe whether the investors short-sell the stocks of the issuing firm. Third, PIPE securities are usually sold at significant discounts and often include warrants, various convertibility features, repricing rights, and other option-like characteristics. We generally do not have sufficiently detailed information to price all these various security components. ${ }^{31}$

Whereas we cannot observe the profitability of individual transactions of hedge funds, we can investigate whether hedge funds repeatedly invest in PIPE securities and whether hedge funds investing in PIPE securities tend to perform poorly. First, we should expect that hedge funds would stop participating in PIPE investments if these investments are unprofitable. Second, if PIPE investments are unprofitable for hedge funds, then we should observe that hedge funds specializing in PIPEs experience poor performance subsequent to the PIPE investments.

The Sagient Research database identifies over our sample period a total of 1666 different hedge funds, of which 1452 participate in fewer than 10 PIPE transactions. The remaining 214 hedge funds participate, on average, in 23.86 PIPEs over an average time span of 3.58 years. The fact that some

\footnotetext{
${ }^{30}$ Companies cannot generally sell the securities on the open market before their registration statement to the SEC is declared effective. If there are no material problems with the registration statement, it can generally be declared effective within 20 days. Unfortunately, we do not have these effective dates for most of our PIPE transactions. However, we checked a sample of 1757 PIPE transactions between 2003 and 2005 and found that the median filing date occurs 32 days after the close of the PIPE transaction and the median effective date occurs 71 days after the close. The inter-quartile range between the closing and the filing date is $17-58$ days and the inter-quartile range between the closing and the effective date is 38-118 days.

31 A related literature investigates the performance of investors in private equity. Moskowitz and VissingJørgensen (2002) investigate the returns on nonpublic traded equity. Lerner, Schoar, and Wong (2005) compute the performance of different investors in private equity fund investments and show substantial heterogeneity in the performance of different classes of limited partners.
} 
hedge funds invest in multiple PIPE securities over relatively long time periods supports the hypothesis that these PIPE transactions are profitable for hedge funds.

To investigate the performance of hedge funds investing in PIPEs, we merge our database of PIPE investors with the Lipper TASS hedge fund database. Unfortunately, we cannot match all funds between the two databases. ${ }^{32}$ We can find hedge fund investors in TASS for around $30 \%$ of the PIPE transactions with hedge funds as main investors. However, these PIPEs represent about $58 \%$ of the capital raised through PIPE transactions by hedge funds as main investors.

Table 8 summarizes the raw and abnormal performance of hedge funds that recently invested in PIPEs. The abnormal returns are computed by subtracting the return of a comparable hedge fund, which has the same strategy and the nearest asset size according to TASS. If asset size is missing in TASS, then the fund is matched randomly to the contemporaneous return of another fund with the same strategy and with missing assets. ${ }^{33}$ We find that the average return of hedge funds equals $2.03 \%$ in the month they purchase PIPE securities. The performance decreases if we include a longer time window. For example, the average return decreases to $1.02 \%$ per month or about $12 \%$ per year if we consider all the hedge funds that purchased PIPEs during the prior 12 months. ${ }^{34}$ Table 8 also documents that hedge funds purchasing PIPE securities do not significantly underperform matched hedge funds. ${ }^{35}$

Hedge funds investing in PIPEs tend to exhibit relatively favorable annualized Sharpe ratios. ${ }^{36}$ The average Sharpe ratio for hedge funds purchasing PIPEs equals 0.71 .

32 This problem seems to plague hedge fund studies that use the available databases. Liang (2000) argues that the TASS database is generally superior to the HFR (Hedge Fund Research) database. He shows that there is not a very large overlap in the coverage between different hedge fund databases. For example, in $1997 / 1998$ there were 465 live and dead funds included in both TASS and HFR. However, 697 funds in HFR were not included in TASS and 1162 funds in TASS were not included in HFR.

33 The hedge funds purchasing PIPEs and the matched hedge funds have similar risk exposures. The market beta of hedge funds that purchase PIPEs during the prior 12 months is 0.49 , whereas the beta of matched hedge funds is 0.44 . The average annualized standard deviation over the prior 12 months of hedge funds purchasing PIPEs is $14.4 \%$, whereas the corresponding standard deviation for matched hedge funds is $13.8 \%$.

34 The longer term performance results are also consistent with the monthly raw returns of funds in the TASS database that list "Reg-D" as an investment focus. The raw return of these hedge funds is $0.84 \%$ per month over our sample period and exceeds significantly the return of matched funds. Regulation D concerns the limited sale and offering of securities without registration and covers PIPE securities.

35 Consistent with Fung and Hsieh (2000) we find a significant "instant history bias." Eliminating backfilled returns tends to reduce the levels of the returns. For example, the average raw returns of hedge funds investing in PIPEs equals 2.14 (current month), 1.21 (6 months), 0.81 (12 months), and 0.54 (24 months) after eliminating backfilled returns.

${ }^{36}$ The Sharpe ratio is computed for each hedge fund as the ratio between the mean annualized excess return of the fund relative to the risk-free rate divided by the annualized standard deviation of the return over the time period between the first PIPE investment and 24 months after the last PIPE investment. 
Table 8

Performance of hedge funds investing in PIPE securities

\begin{tabular}{|c|c|c|c|c|c|c|}
\hline & \multicolumn{3}{|c|}{$\begin{array}{l}\text { Monthly raw return of hedge funds } \\
\text { invested in PIPEs }(\%)\end{array}$} & \multicolumn{3}{|c|}{$\begin{array}{l}\text { Monthly abnormal return of hedge } \\
\text { fund invested in PIPEs relative } \\
\text { to matched hedge fund }(\%)\end{array}$} \\
\hline & $\begin{array}{l}\text { All } \\
\text { PIPEs }\end{array}$ & $\begin{array}{l}\text { Traditional } \\
\text { PIPEs }\end{array}$ & $\begin{array}{l}\text { Structured } \\
\text { PIPEs }\end{array}$ & $\begin{array}{l}\text { All } \\
\text { PIPEs }\end{array}$ & $\begin{array}{l}\text { Traditional } \\
\text { PIPEs }\end{array}$ & $\begin{array}{c}\text { Structured } \\
\text { PIPEs }\end{array}$ \\
\hline $\begin{array}{l}\text { Current } \\
\text { month }\end{array}$ & $\begin{array}{l}2.03^{* * *} \\
(0.36) \\
{[477]}\end{array}$ & $\begin{array}{l}2.20^{* * *} \\
(0.49) \\
{[333]}\end{array}$ & $\begin{array}{l}1.69^{* * *} \\
(0.27) \\
{[161]}\end{array}$ & $\begin{array}{c}0.49 \\
(0.45) \\
{[477]}\end{array}$ & $\begin{array}{c}0.12 \\
(0.62) \\
{[333]}\end{array}$ & $\begin{array}{l}1.31^{* * *} \\
(0.43) \\
{[161]}\end{array}$ \\
\hline 6 months & $\begin{array}{l}1.40^{* * *} \\
(0.19) \\
{[1525]}\end{array}$ & $\begin{array}{l}1.38^{* * *} \\
(0.23) \\
{[1236]}\end{array}$ & $\begin{array}{l}1.45^{* * *} \\
(0.23) \\
{[520]}\end{array}$ & $\begin{array}{l}0.60^{* * *} \\
(0.23) \\
{[1525]}\end{array}$ & $\begin{array}{l}0.53^{* *} \\
(0.27) \\
{[1236]}\end{array}$ & $\begin{array}{l}0.68^{* *} \\
(0.34) \\
{[520]}\end{array}$ \\
\hline 12 months & $\begin{array}{l}1.02^{* * *} \\
(0.15) \\
{[2216]}\end{array}$ & $\begin{array}{l}0.97^{* * *} \\
(0.18) \\
{[1881]}\end{array}$ & $\begin{array}{l}1.20^{* * *} \\
(0.21) \\
{[780]}\end{array}$ & $\begin{array}{l}0.37^{* * *} \\
(0.18) \\
{[2216]}\end{array}$ & $\begin{array}{c}0.33 \\
(0.21) \\
{[1881]}\end{array}$ & $\begin{array}{l}0.61^{* *} \\
(0.28) \\
{[780]}\end{array}$ \\
\hline 24 months & $\begin{array}{l}0.80^{* * *} \\
(0.12) \\
{[3161]}\end{array}$ & $\begin{array}{l}0.76^{* * *} \\
(0.14) \\
{[2759]}\end{array}$ & $\begin{array}{l}1.07^{* * *} \\
(0.18) \\
{[1084]}\end{array}$ & $\begin{array}{c}0.18 \\
(0.15) \\
{[3161]}\end{array}$ & $\begin{array}{c}0.17 \\
(0.16) \\
{[2759]}\end{array}$ & $\begin{array}{c}0.31 \\
(0.23) \\
{[1084]}\end{array}$ \\
\hline
\end{tabular}

The table summarizes the performance of hedge funds that recently invested in PIPE securities by security structure (traditional vs. structured). The abnormal returns are computed by subtracting the return of a hedge fund that has the same strategy and the nearest asset size according to TASS. If asset size is missing in TASS, then the fund is matched randomly to the contemporaneous return of another fund with the same strategy and with missing assets. The returns are expressed in percent and are computed at a monthly frequency. The standard errors are summarized in parentheses. The number of monthly observations for each sample is noted in brackets. '*', '**', and '***' denote abnormal returns that are statistically different from zero at the 10,5 , and $1 \%$ significance levels.

The persistent activity of hedge funds in the PIPE market and the relatively strong performance of hedge funds involved in PIPE transactions indicate that being a lender of last resort pays off for hedge funds, even if the underlying stocks perform relatively poorly.

\section{Conclusions}

This paper discusses the role of hedge funds in private placements. We find investments by hedge funds are associated with significantly negative longrun performance of the underlying equity, even after controlling for the security type. On the other hand, we find little to no abnormal performance in firms issuing traditional private placements to other investors.

We find evidence consistent with the fact that firms that sell their equity to hedge funds have few alternatives to raise external financing because of severe information asymmetries and poor operating performance. Firms that obtain equity financing from hedge funds tend to be smaller and riskier and are less likely to have analyst coverage compared to firms that obtain financing from other investor classes. The firms that obtain equity financing from hedge funds also are more likely to sell their securities at a greater discount and with more warrants and shorter times to first conversion. 
Hedge funds are well suited to act as investors of last resort. Either by negotiating repricing rights, shorting the underlying security, or other means, hedge funds are able to reduce their risk in what could otherwise be a high-risk and illiquid position. Thus, hedge funds might be more willing to invest in firms that otherwise would be shut out of the external capital market. We also show that hedge funds that invest in PIPE securities tend to perform relatively well, even though the companies they invest in perform poorly. Our results are consistent with the hypothesis that hedge funds act as investors of last resort, playing an important role in the market for young, high-risk firms with substantial asymmetric information and large capital needs.

\section{Appendix A: Detailed security structures}

This appendix describes the various PIPE securities in more detail. Securities (1-4) are traditional PIPEs and securities (5-10) are structured PIPEs.

(1) The most basic security is a common stock PIPE, where a fixed number of shares are issued and sold at a predetermined discount to the market price. A common stock PIPE sometimes includes warrants that let the investor purchase additional shares at a fixed price during a specific time period.

(2) A fixed convertible preferred stock PIPE represents equity ownership that is ranked higher than common stock in case of bankruptcy or liquidation. A fixed convertible yields a current return through dividend payments and can be converted by the investor into a fixed number of shares of the company's common stock at a predetermined ratio. The implied fixed conversion price is usually above the current market price. The investor in a fixed convertible exchanges the PIPE security for common stocks if the stock price is sufficiently high on the conversion date.

(3) A fixed convertible debt PIPE is a loan obligation of the company that ranks higher than any equity securities and pays a current interest rate. The other specifications are identical to a fixed convertible preferred stock.

(4) A small number of PIPEs are shelf sales of common stocks, which are sales of a company's common stock from an existing shelf registration statement. The registration allows the company to sell the securities over a period of time.

(5) A floating convertible preferred stock PIPE has a variable conversion price that is based on the future market price of the common stock after the issuance. This feature protects the investor if the price of the common stock changes after the PIPE deal is closed, because the investor will receive an increasing number of shares if the stock price decreases. Floating convertibles often include caps and floors, which limit the possible range of conversion prices.

(6) A floating convertible debt PIPE has similar specifications as a floating convertible preferred stock PIPE, except for the ranking in case of bankruptcy or liquidation.

(7) A structured equity line is an agreement that requires the investor to purchase a predetermined value of the company's common stock over a certain period of time. The price of the stock is usually determined as an average of the closing prices during a pre-specified period in the future minus a fixed discount.

(8) A small number of common stock private placements are classified as common stock reset PIPEs. These deals include repricing rights, which allow the investor to receive additional shares of common stocks if the market price decreases after the closing 
date. The repricing clause functions very similarly to a floating convertible in that the number of shares issuable can change every day.

(9) A reset convertible preferred stock PIPE has a fixed conversion price that is subject to a number of resets at specific times following the closing date. At the time of each of the resets, the fixed conversion price is adjusted as a percentage of the current market price and then remains fixed at this new price until the next reset date.

(10) A reset convertible debt PIPE is similar to a reset convertible preferred stock PIPE except for the ranking in case of bankruptcy or liquidation.

\section{Appendix B: Estimation methodology}

This section explains the methodology used to perform the event study in Section 3. First, we download from CRSP the SIC codes and the market capitalizations at the end of each calendar year of all the common stocks that are not closed-end funds, ADRs, REITs, and that are headquartered in the U.S. We merge this data set with the corresponding book-to-market ratios from Compustat. For companies with fiscal-year-ends before October, we use the book value at the end of the current fiscal year; and for companies with fiscal-year-ends after September, we use the book values at the end of the previous fiscal year to allow some time delay for the publication of the accounting values after the end of the fiscal year.

Second, we match companies according to their industry classification, size, book-tomarket ratio, and momentum. We classify all the companies into 48 industries according to the SIC codes, as described in Fama and French (1997). ${ }^{37}$ We rank the companies in each of these 48 industries by their market capitalization, their book-to-market ratio, and their return during the previous 12 months. We match each company monthly to another company in the same industry that did not issue a PIPE in the previous two years so that the sum of the absolute deviations of the size, the book-to-market ratio, and the momentum rankings is smallest. If the size, the book-to-market ratio, or the momentum returns are missing, then we match the company to another company in the same industry group with missing size, book-to-market ratio, or momentum returns. The distribution of the characteristics for the PIPE and the comparable companies is very close.

Third, we compute the daily buy-and-hold returns for all companies in our sample during a 750 trading day window starting 250 days prior to the close of the PIPE transaction. If the returns for a company that issues a PIPE are not available in CRSP, we set the returns equal to the returns of the matched company. If the holding period returns for a matched company are not available in CRSP, then we replace this company with the company that had the next-closest match at the end of the calendar year prior to the closing date of the PIPE.

Fourth, we compare these average returns for different PIPE deals over various sample periods. The abnormal return is defined as the difference between the buy-and-hold return of the PIPE company and the buy-and-hold return of the matched company.

\section{Appendix C: Compustat data definitions}

This section explains the accounting variables used in the previous regressions. All data are obtained from Compustat. The Compustat data items used are as follows: total assets (item 6); book equity [total assets - total liabilities (item 181) - preferred stock (item 10 or, if missing, item 56) + deferred taxes (item 35) + convertible debt (item 79)]; book debt

\footnotetext{
${ }^{37}$ The industry classification can be obtained from Kenneth French's Web site: http://mba.tuck.dartmouth.edu/pages/faculty/ken.french/Data_Library
} 
[total assets - book equity]; leverage [book debt/total assets]; book-to-market ratio [common equity (item 60$) /($ common shares used to calculate EPS (item 54$) \times$ fiscal year close price (item 199)]; return on assets [net income (item 172)/total assets (item 6)]; capital expenses and $R \& D$ relative to assets [capital expenditures (item 128) + research and development expenses (item 46 )/total assets (item 6)].

\section{References}

Aboody, D., and B. Lev. 2000. Information Asymmetry, R\&D and Insider Gains. Journal of Finance $55: 2747-66$

Ackermann, C., R. McEnally, and D. Ravenscraft. 1999. The Performance of Hedge Funds: Risk, Return and Incentives. Journal of Finance 54:833-74.

Agarwal, V., and N. Y. Naik. 2004. Risks and Portfolio Decisions Involving Hedge Funds. Review of Financial Studies 17(1):63-8.

Asquith, P., P. A. Pathak, and J. R. Ritter. 2005. Short Interest, Institutional Ownership, and Stock Returns. Journal of Financial Economics 78:243-76.

Ball, R., S. P. Kothari, and J. Shanken. 1995. Problems in Measuring Portfolio Performance: An Application to Contrarian Investment Strategies. Journal of Financial Economics 38:79-107.

Barber, B. M., and J. D. Lyon. 1997. Detecting Long-Run Abnormal Stock Returns: The Empirical Power and Specification of Test Statistics. Journal of Financial Economics 43:341-72.

Barclay, M. J., C. G. Holderness, and D. P. Sheehan. 2005. Private Placements and Managerial Entrenchment, working paper, University of Rochester.

Brav, A., and P. A. Gompers. 1997. Myth or Reality? The Long-Run Underperformance of Initial Public Offerings: Evidence from Venture and Nonventure Capital-Backed Companies. Journal of Finance 52:1791-821.

Brennan, M. J., and A. Subrahmanyam. 1995. Investment Analysis and Price Formation in Securities Markets. Journal of Financial Economics 38:361-81.

Brown, S. J., and W. N. Goetzmann. 2003. Hedge Funds with Style. Journal of Portfolio Management 29(Winter):101-12.

Brown, S. J., W. N. Goetzmann, and R. G. Ibbotson. 1999. Offshore Hedge Funds: Survival and Performance, 1989-95. Journal of Business 72:91-117.

Brown, S. J., W. N. Goetzmann, and J. M. Park. 2000. Hedge Funds and the Asian Currency Crisis Journal of Portfolio Management 26(Summer):95-101.

Brown, S. J., W. N. Goetzmann, and J. M. Park. 2001. Careers and Survival: Competition and Risk in the Hedge Fund and CTA Industry. Journal of Finance 56:1869-86.

Brunnermeier, M. K., and S. Nagel. 2004. Hedge Funds and the Technology Bubble. Journal of Finance 59:2013-40.

Carhart, M. M. 1997. On Persistence in Mutual Fund Performance. Journal of Finance 52:57-82.

Carlson, M., A. Fisher, and R. Giammarino. 2006. SEOs, Real Options, and Risk Dynamics: Empirical Evidence, working paper, University of British Columbia.

Chaplinsky, S., and D. Haushalter. 2005. Financing under Extreme Uncertainty: Evidence from PIPEs, working paper, University of Virginia.

Chemmanur, T. J., and P. Fulghieri. 1999. A Theory of the Going-Public Decision. Review of Financial Studies 12:249-79.

Chou, D., M. Gombola, F. Liu. 2004. Earnings Management and the Underperformance of Private Placements of Equity, working paper, Drexel University.

D'Avolio, G. 2002. The Market for Borrowing Stock. Journal of Financial Economics 66:271-306. 
Diether, K., C. Malloy, and A. Scherbina. 2002. Differences of Opinion and the Cross-Section of Stock Returns. Journal of Finance 57:2113-41.

Eckbo, B. E., R. W. Masulis, and O. Norli. 2000. Seasoned Public Offerings: Resolution of the 'New Issues Puzzle'. Journal of Financial Economics 56:251-91.

Fama, E. 1998. Market Efficiency, Long-Term Returns, and Behavioral Finance. Journal of Financial Economics 49:283-306.

Fama, E. F., and K. R. French. 1993. Common Risk Factors in the Return on Bonds and Stocks. Journal of Financial Economics 33:3-53.

Fama, E. F., and K. R. French. 1997. Industry Costs of Equity. Journal of Financial Economics 43:153-93.

Ferson, W. E., and R. W. Schadt. 1996. Measuring Fund Strategy and Performance in Changing Economic Conditions. Journal of Finance 51:425-61.

Fung, W., and D. A. Hsieh. 1997. Empirical Characteristics of Dynamic Trading Strategies: The Case of Hedge Funds. Review of Financial Studies 10:275-302.

Fung, W., and D. A. Hsieh. 1999. A Primer on Hedge Funds. Journal of Empirical Finance 6:309-31.

Fung, W., and D. A. Hsieh. 2000a. Measuring the Market Impact of Hedge Funds. Journal of Empirical Finance 7:1-36.

Fung, W., and D. A. Hsieh. 2000b. Performance Characteristics of Hedge Funds and CTA Funds: Natural Versus Spurious Biases. Journal of Financial and Quantitative Analysis 35:291-307.

Fung, W., and D. A. Hsieh. 2001. The Risk in Hedge Fund Strategies: Theory and Evidence from Trend Followers. Review of Financial Studies 14:313-41.

Fung, W., D. A. Hsieh, N. Y. Naik, and T Ramadorai. 2006. Hedge Funds: Performance, Risk and Capital Formation, working paper, London Business School.

Gomes, A., and G. Phillips. 2005. Why Do Public Firms Issue Private and Public Equity, Convertibles and Debt? working paper, Washington University.

Gupta, A., and B. Liang. 2005. Do Hedge Funds Have Enough Capital? A Value-at-Risk Approach. Journal of Financial Economics 77:219-53.

Habib, M. A., and D. B. Johnsen. 2000. The Private Placement of Debt and Outside Equity as an Information Revelation Mechanism. Review of Financial Studies 13:1017-55.

Hertzel, M., and R. L. Smith. 1993. Market Discounts and Shareholder Gains for Placing Equity Privately. Journal of Finance 48:459-85.

Hertzel, M., M. Lemmon, J. S. Linck, and L. Rees. 2002. Long-run Performance Following Private Placements of Equity. Journal of Finance 59:2595-617.

Hillion, P., and T. Vermaelen. 2004. Death Spiral Convertibles. Journal of Financial Economics 71:381-415.

Jagannathan, R., A. Malakhov, and D. Novikov. 2006. Do Hot Hands Persist Among Hedge Fund Managers? An Empirical Evaluation, working paper, Northwestern University.

Krishnamurthy, S., P. Spindt, V. Subramaniam, and T. Woidtke. 2005. Does Investor Identity Matter in Equity Issues? Evidence from Private Placements. Journal of Financial Intermediation 14:210-38.

Lerner, J., A. Schoar, and W. Wong. 2005. Smart Institutions, Foolish Choices? The Limited Partner Performance Puzzle, working paper, Harvard University.

Liang, B. 2000. Hedge Funds: The Living and the Dead. Journal of Financial and Quantitative Analysis 35(3):309-26.

Loughran, T., and J. R. Ritter. 1995. The New Issues Puzzle. Journal of Finance 50:23-51.

Loughran, T., and J. R. Ritter. 1997. The Operating Performance of Firms Conducting Seasoned Equity Offerings. Journal of Finance 52:1823-50. 
Lyandres, E., L. Sun, and L. Zhang. 2006. Investment-Based Underperformance Following Seasoned Equity Offerings, working paper, Rice University.

Lyon, J. D., B. M. Barber, and C. Tsai. 1999. Improved Methods for Tests of Long-Run Abnormal Returns. Journal of Finance 54:165-201.

Meidan, D. 2005. The Informativeness of Offer Characteristics Versus Investor Identity in PIPE Transactions, working paper, Northwestern University.

Mitchell, M. L., and E. Stafford. 2000. Managerial Decisions and Long-Run Stock Price Performance. Journal of Business 73:287-320.

Moskowitz, T. J., and A. Vissing-Jørgensen. 2002. The Returns to Entrepreneurial Investment: A Private Equity Premium Puzzle? American Economic Review 92:745-78.

Nagel, S. 2005. Short Sales, Institutional Investors and the Cross-Section of Stock Returns. Journal of Financial Economics 78:277-309.

Shumway, T. 1997. The Delisting Bias in CRSP Data. Journal of Finance 52(1):327-40.

Spiess, D. K., and J. Affleck-Graves. 1995. Underperformance in Long-Run Stock Returns Following Seasoned Equity Offerings. Journal of Financial Economics 38:243-67.

Stein, J. 1992. Convertible Bonds as ‘Backdoor’ Equity Financing. Journal of Financial Economics 32:3-22.

Wruck, K. H. 1989. Equity Ownership Concentration and Firm Value. Evidence from Private Equity Financings. Journal of Financial Economics 23:3-28.

Wruck, K. H., and Y. L. Wu. 2005. The Value of Relationship Investing: Evidence from Private Placements of Equity by U.S. Public Firms, working paper, Ohio State University.

Wu, Y. L. 2004. The Choice of Equity-Selling Mechanisms. Journal of Financial Economics 74:93-119.

Wu, X., Z. Wang, and J. Yao. 2005. Understanding the Positive Announcement Effects of Private Equity Placements: New Insights from Hong Kong Data. Review of Finance 9(3):385-414. 